NBER WORKING PAPER SERIES

\title{
DISTORTION COSTS OF TAXING WEALTH ACCUMULATION: INCOME VERSUS ESTATE TAXES
}

\author{
Douglas Holtz-Eakin \\ Donald Marples \\ Working Paper 8261 \\ http://www.nber.org/papers/w8261
NATIONAL BUREAU OF ECONOMIC RESEARCH 1050 Massachusetts Avenue
Cambridge, MA 02138
April 2001

We thank Gary Engelhardt for many useful conversations. Alan Auerbach, Michael Brunetti, William Gale, David Joulfaian, Louis Kaplow, Janet McCubbin, James Poterba, Antonio Rangel, Harvey Rosen, Andrew Samwick, and Roberton Williams provided valuable comments on an earlier draft. We thank Esther Gray and Mary Santy for their help in preparing the manuscript. The views expressed herein are those of the authors and not necessarily those of the National Bureau of Economic Research.

(C) 2001 by Douglas Holtz-Eakin and Donald Marples. All rights reserved. Short sections of text, not to exceed two paragraphs, may be quoted without explicit permission provided that full credit, including $($ C notice, is given to the source. 
Distortion Costs of Taxing Wealth Accumulation: Income Versus Estate Taxes

Douglas Holtz-Eakin and Donald Marples

NBER Working Paper No. 8261

April 2001

JEL No. H2

\section{ABSTRACT}

Recently, attention has focused on the estate tax. To date, however, the debate over estate taxes has been nearly devoid of standard considerations of deadweight loss. We develop a framework for computing the deadweight loss of a revenue-neutral switch from an estate tax to a capital income tax, focusing on the potential lifetime behavioral responses in anticipation of paying the estate tax, while requiring relatively few parameters to estimate. We conclude that eliminating the estate tax and replacing the revenue with that from a capital income tax will likely enhance economic efficiency. Specifically, using our baseline parameter estimates we estimate that the mean decrease in deadweight loss is $\$ 0.018$ per dollar of wealth. There is, however, considerable heterogeneity in the estimated impact. Importantly, our estimates are based on data that do not contain the "super-rich" who are most highly affected by the estate tax.

Douglas Holtz-Eakin

Center for Policy Research

Department of Economics

Syracuse University

Syracuse, NY 13244-1020

and NBER

(315) 443-9464

djheakin@maxwell.syr.edu
Donald Marples

Center for Policy Research

Department of Economics

Syracuse University

Syracuse, NY 13244-1020

(315) 443-3114

djmarple@maxwell.syr.edu 


\section{1. $\underline{\text { INTRODUCTION }}$}

In recent years there has been considerable attention devoted to the impact of taxes on the incentives to accumulate wealth. One manifestation of this interest has been the widespread debate over the desirability of "fundamental" tax reform, generally taking the form of a consumption-based tax system. These systems exempt from tax wealth accumulation until the point at which it is consumed. ${ }^{1}$

More recently, attention has focused on repeal of the estate tax (more properly, the federal estate and gift taxes as embodied in the Unified Transfer Tax). For example, in 2000 Congress passed a repeal of the estate tax, which was vetoed by President Clinton. An interesting feature of the "repeal" was that it eliminated the estate and gift tax, but added a new tax on wealth accumulation: a repeal of the "basis step-up" at death that serves to eliminate the tax liability on all capital gains accrued during the decedent's life. Since both taxes reduce the return to wealth accumulation, an obvious question is: which is better? "Better" is, of course, a normative judgment that hinges on an array of features of any tax-its efficiency cost, incidence, administrability, compliance cost, and so forth. To date, however, the debate over estate taxes has been nearly devoid of standard considerations of deadweight loss.

This is both surprising and unfortunate. It is surprising because the large body of anecdotal critique of the tax reverberates with the type of tax-induced behavioral responsetailoring portfolios for tax purposes, setting up trusts, altering corporate structures, spending more when alive - that are the cornerstone of efficiency costs. And it is unfortunate because a balanced assessment of the estate tax, indeed the tax system as a whole, requires inclusion of these distortion costs. 
The purpose of this paper is to begin to fill this gap in the analysis of the estate tax. Specifically, in the next section we develop a framework for computing the deadweight loss of a revenue-neutral switch from a capital income tax to an estate tax. One reason for the paucity of empirical research on the estate tax is the difficulty in obtaining data suitable for the task. Hence, our framework is tailored to require relatively few parameters to estimate. In Section 3 we discuss the estate tax institutions, describe our data, and discuss estimation of effective estate tax rates. Section 4 contains our estimates of key behavioral parameters, while Section 5 presents the efficiency computations. The final section is a summary with suggestions for future research.

To anticipate the bottom line, we conclude that eliminating the estate tax and replacing the revenue with that from a capital income tax will likely enhance economic efficiency. Specifically, using our baseline parameter estimates we estimate that the mean decrease in deadweight loss is $\$ 0.018$ per dollar of wealth. There is, however, the estimated impact differs greatly across individuals. We explore this extensively below. Importantly, our estimates are based on data that do not contain the "super-rich." That is, our estimates of the potential efficiency gains exclude the impacts on those most highly affected by the estate tax.

\section{2. $\quad$ ANALYTIC FRAMEWORK}

Our strategy is to set the estate tax in the context of the lifetime decisions to work, save, donate to charities, and leave bequests. There is, however, a premium on simplicity, so we begin with the familiar two-period characterization of a household's life-cycle. During the working years, households use (inherited) initial wealth $\left(W_{0}\right)$ and labor earnings to finance consumption and saving according to

$$
W_{O}+v(L-l)=C_{O}+S
$$


where $v$ is the wage, $l$ is leisure, $C_{O}$ is working-age consumption and $S$ is saving. The latter earns a gross return $r$ that is subject to a capital income tax at rate $\theta .^{2}$ Thus, at the start of the second period of life, wealth $\left(W_{1}\right)$ accumulates to

$$
S(1+r(1-\theta))=W_{1}
$$

During the later stage of life, the household divides wealth between old-age consumption, $C_{1}$, and the total estate, $E$

$$
W_{1}=C_{1}+E
$$

In turn, the estate is allocated among a variety of uses. First, the household may choose to leave a bequest, $B$, directly to its heirs. ${ }^{3}$ Alternatively, a portion of the estate may be dedicated to charitable bequests, $C B$, with the distinction that the latter are deductible from the estate tax. In addition, the household may choose to hold some of its estate wealth in forms that avoid the estate tax, $A$. The latter are meant to capture the ability of households to undertake legal avoidance schemes such as trusts and so forth. ${ }^{4}$ Finally, the estate will be devoted as well to payment of the estate tax itself, which we assume is levied at the flat rate $\tau$. Recognizing that $C B$ and $A$ avoid the tax, the estate must satisfy

$$
E=C B+A+B+\tau[E-C B-A]
$$

which may be re-arranged to yield

$$
E=C B+A+\frac{1}{1-\tau} B
$$

As (4') makes transparent, the most apparent effect of the estate tax is to raise the price of direct bequests relative to other uses of estate wealth. Combining (4'), (2) and (3) shows the linkages between saving, consumption, and estate-related activities ${ }^{5}$

$$
W_{1} \equiv S(1+r(1-\theta))=C_{1}+C B+A+\frac{1}{1-\tau} B
$$


Finally, combining the old-age budget (3') with the working-age budget yields the lifetime budget constraint of the household

$$
W_{O}+v L=C_{O}+v \ell+\frac{1}{[1+r(1-\theta)]}\left\{C_{1}+C B+A\right\}+\frac{1}{[1+r(1-\theta)](1-\tau)} B
$$

Our goal is to focus on deadweight loss, which derives from the difference between posttax and pre-tax prices; i.e., from effective tax wedges. With an eye to this, we write the budget constraint as

$$
W_{O}+v L=C_{O}+q_{\ell} \ell+q_{1} C_{1}+q_{C B} C B+q_{A} A+q_{O} B
$$

where $q$ 's are post-tax prices. Letting $p$ 's denote pre-tax prices, it is straightforward to see that the price of leisure is unaffected by the tax. However, the prices of the remaining choices $-C_{1}$, $B, A$, and $C B$-are altered by the tax system. Noting that the pre-tax prices are

$$
\begin{aligned}
& p_{\ell}=q_{l}=v \\
& p_{1}=p_{C B}=p_{A}=p_{B}=\frac{1}{1+r}
\end{aligned}
$$

and letting $t$ 's denote the respective effective excise taxes (e.g., for $\left.C_{1}, q_{1}=p_{1}+t_{1}\right)$, one can see that the presence of the capital income tax induces effective excise taxes according to

$$
\begin{aligned}
& t_{l}=0 \\
& t_{1}=t_{C B}=t_{A} \equiv q_{1}-p_{1}=\frac{\theta r}{(1+r)(1+r(1-\theta))} .
\end{aligned}
$$

That is, the presence of the capital income tax raises the effective prices of old-age consumption, charitable bequests, and avoidance activities. Alternatively, we may present the distortions in terms of ad valorem tax rate rates; i.e. presenting the tax as a fraction of the pre-tax price. Doing so yields

$$
\mu_{1}=\mu_{C B}=\mu_{A}=\frac{\theta r}{1+r(1-\theta)}
$$


The presence of the estate tax, however, introduces an additional distortion. The post-tax price of bequests includes not only the tax on carrying wealth into old age found in (9), but also an additional estate-based tax on direct transfers to heirs. That is

$$
q_{B}=\left(1+\mu_{B}\right)\left(1+\mu_{1}\right) p_{B}
$$

where

$$
\mu_{B}=\frac{\tau}{1-\tau} .
$$

Our goal is to assess the impact of variations in these taxes on household welfare. ${ }^{6}$ By definition, the deadweight loss of this tax system is the utility decline in excess of that induced by the loss of the tax revenue. Let $V(. .$,$) denote the indirect utility function defined over$ household prices and exogenous resources. Then, adopting the equivalent variation measure of excess burden, letting $R$ denote tax revenues and using $\chi$ to denote the excess burden, the latter is implicitly defined by

$$
V\left(q_{\ell}, q_{1}, q_{C B}, q_{A}, q_{B},\left(v L+W_{o}\right)\right) \equiv V\left(p_{\ell}, p_{1}, p_{C B}, p_{A}, p_{B},\left[\left(v L+W_{o}\right)-R-\chi\right]\right)
$$

That is, $\chi$ is the amount above and beyond $R$ by which household resources must be reduced in the absence of distortionary taxes to lower utility to the level reached in the presence of the capital income and estate taxes.

As examination of equation (12) makes clear, our notion of deadweight loss is quite circumscribed. With regard to the donor, for example, it ignores the role of wealth accumulation as consumption insurance, the value of services received in "exchange" for bequests, and any consumption externalities that spillover from the recipient. From the perspective of the donee and society as a whole, it excludes the welfare effects of changes in consumption, labor supply or human capital accumulation; the valuation of charitable bequests; or the distributional consequences for recipients. In principle, it is entirely desirable to incorporate these 
considerations into a welfare computation. In practice, the informational demands are beyond the scope of our analysis.

To identify the implications for excess burden of altering the estate tax rate in our framework, we differentiate (12) with respect to the ad valorem tax rate $\mu_{B}$

$$
\left[\frac{\partial V}{\partial q_{1}} \frac{\partial q_{1}}{\partial \mu_{1}}+\frac{\partial V}{\partial q_{C B}} \frac{\partial q_{C B}}{\partial \mu_{1}}+\frac{\partial V}{\partial q_{A}} \frac{\partial q_{A}}{\partial \mu_{1}}+\frac{\partial V}{\partial q_{B}} \frac{\partial q_{B}}{\partial \mu_{1}}\right] \frac{\partial \mu_{1}}{\partial \mu_{B}}+\frac{\partial V}{\partial q_{B}} \frac{\partial q_{B}}{\partial \mu_{B}}=\frac{\partial V}{\partial I}\left\{\frac{-\partial R}{\partial \mu_{B}}-\frac{\partial \chi}{\partial \mu_{B}}\right\}
$$

In deriving (13), we have made the simplifying assumption that labor supply is fixed, and focused instead on saving, avoidance, charity, and bequest issues. ${ }^{7}$ To further clarify (13), we first employ Roy's Identity to obtain

$$
\frac{-\partial V}{\partial q_{1}} / \frac{\partial V}{\partial I}=C_{1}, \frac{-\partial V}{\partial q_{C B}} / \frac{\partial V}{\partial I}=C B, \frac{-\partial V}{\partial q_{A}} / \frac{\partial V}{\partial I}=A, \frac{-\partial V}{\partial q_{B}} / \frac{\partial V}{\partial I}=B
$$

Second, we impose the constraint that the change in taxes be revenue neutral. Thus, the revenueneutral change has deadweight loss implications given by

$$
\left.\frac{\partial \chi}{\partial \mu_{B}}\right|_{d R=0}=p_{1}\left\{C_{1}+C B+A+\left(1+\mu_{B}\right) B\right\} \frac{d \mu_{1}}{d \mu_{B}}+p_{1}\left(1+\mu_{1}\right) B
$$

To proceed, we require $\frac{d \mu_{1}}{d \mu_{B}}$. Revenue is given by

$$
R=\mu_{1} W_{1}+\mu_{B} B
$$

Differentiating (16) yields

$$
d R=0 \Rightarrow \frac{d \mu_{1}}{d \mu_{B}}=\frac{-\left\{B\left[1+\frac{\mu_{B}}{1+\mu_{B}} \varepsilon_{B B}\right]+W_{1}\left[\frac{\mu_{1}}{1+\mu_{B}}\right] \varepsilon_{W B}\right\}}{W_{1}\left[1+\frac{\mu_{1}}{1+\mu_{1}} \varepsilon_{W 1}\right]+B\left(\frac{\mu_{B}}{1+\mu_{1}}\right) \varepsilon_{B 1}}
$$

where the elasticities of wealth with respect to tax policy are given by

$$
\varepsilon_{W B} \equiv \frac{\partial W_{1}}{\partial\left(1+\mu_{B}\right)} \frac{\left(1+\mu_{B}\right)}{W_{1}}, \quad \varepsilon_{W 1} \equiv \frac{\partial W}{\partial\left(1+\mu_{1}\right)} \frac{\left(1+\mu_{1}\right)}{\partial \mu_{1}}
$$


and

$$
\varepsilon_{B B} \equiv \frac{\partial B}{\partial\left(1+\mu_{B}\right)} \frac{\left(1+\mu_{B}\right)}{B}=\frac{\partial B}{\partial\left(1+\mu_{1}\right)} \frac{\left(1+\mu_{1}\right)}{B} \equiv \varepsilon_{B 1}
$$

The latter equality holds because both taxes enter the "price of bequests" proportionally.

Collecting terms, the effect on excess burden of a revenue neutral increase in estate taxation (and reduction in capital income taxation) is given by

$$
\left.\frac{d \chi}{d \mu_{B}}\right|_{d R=0}=p_{1} W_{1}\left\{\frac{B}{W_{1}}\left(1+\mu_{1}\right)-\frac{\frac{B}{W_{1}}\left(1+\frac{\mu_{B}}{1+\mu_{B}} \varepsilon_{B B}\right)+\frac{\mu_{1}}{1+\mu_{B}} \varepsilon_{W B}}{\left(1+\frac{\mu_{1}}{1+\mu_{1}} \varepsilon_{W 1}\right)+\left(\frac{B}{W_{1}}\right)\left(\frac{\mu_{B}}{1+\mu_{1}}\right) \varepsilon_{B B}}\right\}
$$

Equation (20) is the focus of the remainder. ${ }^{8}$ Several features merit attention. First, because both the capital income tax and the estate tax are taxes on wealth accumulation, deadweight loss (or gain) is greater or smaller with the amount of wealth that they affect—-hence the term $p_{1} W_{1}$.

Second, as noted above, the primary additional impact of the estate tax is to change the relative price of bequests versus other uses of wealth. For this reason, the distortion cost is intimately related to the fraction of wealth devoted to bequests. ${ }^{9}$ Note, however, that the efficiency tradeoff is not monotonic with respect to the bequest share. Intuitively, as the bequest share becomes larger, the "late-life" distortion introduced by raising the price of bequests becomes larger. However, as the bequest share falls the relative size of the inter-temporal distortion becomes more important.

Third, the expression in (20) imposes relatively modest informational requirements on the analyst. It is written in terms of uncompensated behavioral elasticities, and requires estimates of only three responses. The first, the elasticity of wealth accumulation with respect to its excise tax, summarizes the impact (from a deadweight loss point of view) of distortions to late-life 
consumption, charitable bequests, and avoidance activities on the incentives to accumulate wealth. The elasticity of wealth with respect to the capital income tax summarizes similar information for the capital income tax. Finally, the elasticity of bequests with respect to the estate tax summarizes the distortion to the mix of late-life activities.

Thus, replacing the estate tax with a capital income tax has two effects. First, it removes the distortion between direct bequests and the composite activity comprised of second period consumption, charitable bequests, and avoidance activities. The latter two categories — which include all manner of trusts, family foundations, family-specific business arrangements_ — are a notorious component of avoidance activity. On the basis of anecdotal evidence, one would expect that they might display a fairly elastic response to the estate tax.

Second, replacing the estate tax with a capital income tax replaces one distortion of the inter-temporal allocation of consumption with another. Note, however, that a mechanical application of equation (20) indicates that excess burden could rise by taxing estates, even when bequests are completely inelastic $\left(\varepsilon_{B B}=0\right)$, a reflection of the fact that our formula is written in terms of uncompensated elasticities.

It is useful to get a feel for plausible magnitudes of the parameters of equation (20). Consider first the elasticity of wealth accumulation, which indexes the responsiveness of saving by a forward-looking household in anticipation of an estate tax liability. Since the estate tax rate, $\tau$, does not enter any budget constraint in isolation, it is not surprising that the wealth elasticity in equation (20) is not directly related to the estate tax rate. Instead, the two are linked by

$$
\varepsilon_{W B} \equiv \frac{\partial W_{1}}{\partial\left(1+\mu_{B}\right)} \frac{\left(1+\mu_{B}\right)}{W_{1}}=\left(\frac{\partial W}{\partial \tau} \frac{\tau}{W_{1}}\right) \frac{\partial \tau}{\partial\left(1+\mu_{B}\right)} \frac{\left(1+\mu_{B}\right)}{\tau}=\left(\frac{\partial W}{\partial \tau} \frac{\tau}{W_{1}}\right)\left(\frac{1-\tau}{\tau}\right)
$$

Consider the following. As we will see below, the expected (i.e., mortality adjusted, presentvalue) estate tax rate is roughly 3.5 percent. Suppose that the elasticity of wealth with respect to 
$\tau$ is -0.5 . Then, equation (21) implies that we would observe an elasticity with respect to $\left(1+\mu_{B}\right)$

of -13.8 . Even a much more modest elasticity with respect to $\tau$ of -0.05 translates to a value of $\varepsilon_{W B}$ equal to -1.4. Replacing wealth with the bequest in this line of reasoning makes clear that the same considerations that apply to $\varepsilon_{W B}$ are relevant in scaling $\varepsilon_{B B}$,

With this background, we can anticipate the same logic in the capital income tax. The link between $\varepsilon_{W 1}$ and the conventional "tax elasticity" is given by:

$$
\varepsilon_{W 1} \equiv \frac{\partial W_{1}}{\partial\left(1+\mu_{1}\right)} \frac{\left(1+\mu_{1}\right)}{W_{1}}=\left(\frac{\partial W}{\partial \theta} \frac{\theta}{W_{1}}\right) \frac{\partial \theta}{\partial\left(1+\mu_{1}\right)} \frac{\left(1+\mu_{1}\right)}{\theta}=\left(\frac{\partial W}{\partial \theta} \frac{\theta}{W_{1}}\right)\left(\frac{1+r(1-\theta)}{r \theta}\right)
$$

Suppose that the real return is 8 percent, that the effective rate of capital income taxation $(\theta)$ is 10 percent, and that the elasticity of wealth accumulation with respect to the income tax is 0.1 . That is, there is a modest positive elasticity in which the income effect outweighs the substitution effect. These assumptions imply $\varepsilon_{W 1}$ is roughly 13. Of course, should the substitution effect outweigh the income effect, we would anticipate comparably-sized, but negative elasticities.

As opposed to focusing on the components of the deadweight loss expression in equation (20), we might instead get a feel for some plausible magnitudes for the "bottom line" estimates. To build on the previous examples, suppose, for example, that $\varepsilon_{W B}=\varepsilon_{B B}=\varepsilon_{W 1}=-1.4$; i.e., wealth accumulation and bequest behavior are all modestly reduced by capital income and estate taxes. Then, assuming that bequests are only 10 percent of wealth accumulation $\left(\frac{B}{W_{1}}=0.1\right)$, equation (20) indicates that the change in deadweight loss per dollar of wealth $\left(\frac{\partial X}{\partial \mu_{B}} / P W_{1}\right)$ is just under $0.015 .{ }^{10}$ That is, there is a modest efficiency gain from reducing estate taxes and replacing the revenue via a capital income tax. The same qualitative conclusion holds true if we 
reduce the uncompensated bequest elasticity to zero; $\varepsilon_{B B}=0$. In this instance, the efficiency gain is smaller (0.01 per dollar of wealth).

Of course, more substantial elasticities yield more dramatic results. If $\varepsilon_{W B}=\varepsilon_{B B}=\varepsilon_{W 1}=-10.0$ (recall from above that this is consistent with relatively small behavioral responses to statutory rates), then we get a result of deadweight loss equal to 0.11 per dollar of wealth. Here there is a substantial efficiency gain to altering the mix of taxes away from the estate tax. Finally, it is clearly possible for the sign of the effect to go the other way-if $\varepsilon_{B B}=0$ and $\varepsilon_{W B}=\varepsilon_{W 1}=-1.4$, then equation (20) implies an efficiency gain to relying more heavily on the estate tax equal to 0.01 per dollar of wealth.

The source of efficiency effects is easily linked to the kinds of stories that surround the estate tax. Note that ( $\left.3^{\prime}\right)$ implies the following relationship among the responses to the estate tax

$$
\varepsilon_{W B}=(1-\lambda) \varepsilon_{X B}+\lambda\left(1+\varepsilon_{B B}\right)
$$

where $X \equiv C_{1}+C B+A, \lambda \equiv \frac{B}{W_{1}}$, and $\varepsilon_{X B}$ is defined analogous to $\varepsilon_{W B}$ and $\varepsilon_{B B}$. As noted earlier, there is substantial anecdotal evidence that avoidance $(A)$ responds strongly to the estate tax, and previous research (see, e.g., Joulfaian [2000]) documents a sizeable elasticity of charitable giving with respect to the estate tax. Thus, one might expect that $\varepsilon_{X B}$ is fairly large. Using (23),

$$
\varepsilon_{X B}=\frac{\varepsilon_{W B}-\lambda\left(1+\varepsilon_{B B}\right)}{1-\lambda} .
$$

Now, assume (as above) that $\varepsilon_{W B}=-13.8$. Further, let $\varepsilon_{B B}=-2.8$ (corresponding to an elasticity with respect to $\tau$ of -0.1 ), and let $\lambda=0.1$. Then $\varepsilon_{X B}$ will be roughly -15.1 . That is, the decisions that one would expect, a priori to be most elastic will, in fact, be more responsive than either $W_{1}$ or $B$. 
To summarize, the good news is that the approach requires only modest amounts of information on individual responses to the estate tax. Unfortunately, the corresponding bad news is that we know relatively little about the key elasticities. Hence, one part of our analysis below is to present new evidence regarding household behavior and the estate tax. Before turning to these efforts, we briefly review the institutional features of estate and inheritance taxes in the United States.

\section{ESTATE TAXATION IN THE UNITED STATES}

The Federal estate tax dates to $1916 .{ }^{11}$ Currently, the estate tax is one component of the Federal Unified Transfer Tax, which is composed of the estate tax, the gift tax, and the generation-skipping tax. Mechanically, the estate tax consists of a base and rate schedule. Since the Revenue Act of 1954, the gross estate is comprised of the fair market value of the decedent's

real estate, stocks, bonds, businesses, pensions and the proceeds from life insurance policies. ${ }^{12,13}$

Prior to 1976, the gift tax and the estate tax were not integrated. This provided differential taxation for gifts depending upon the donor's life status. The Tax Reform Act of 1976 (TRA 76) reconciled this discrepancy by integrating the gift and estate taxes and ending the differential taxation. Specifically, equalize the treatment of inter vivos gifts and bequests, lifetime taxable gifts are added to the gross estate to form the tax base. (As noted below, a credit is provided for lifetime gift taxes paid.) ${ }^{14}$

Finally, transfers that skip a generation (e.g., those to a grandchild) are subject to a generation skipping transfer tax (GSTT). If $\$ 1$ of taxable estate was transferred first to a child and then, in turn, from the child to the grandchild, it would be subject to the estate tax twice. Accordingly, there arises an incentive to "skip" a generation, thereby lowering dynastic estate 
taxes. The GSTT ensures that each generation is taxed, by taxing any such transfer in excess of \$1 million at the highest statutory rate, currently 55 percent.

The second basic component of the estate tax is the rate schedule. The federal estate tax rate schedule ranges from 18 percent on the first $\$ 10,000$ of taxable estate to 55 percent on estate in excess of $\$ 3,000,000$. The statutory rate schedule for 1992 is shown in Table 1.

Several credits against tax liability are allowed under the estate and gift tax, the largest of which is the Unified Credit. From 1987 through 1997, the Unified Credit was fixed at \$192,800. This yielded an effective exemption of the first $\$ 600,000$ of estate value per decedent. As a result the effective marginal tax rates begin at 37 percent on taxable estates in excess of \$600,000. The Tax Reform Act of 1997 (TRA97) increases the size of the Unified Credit in steps to $\$ 345,800$ in 2006 , equivalent to an effective exemption of $\$ 1,000,000 .^{15}$

The second largest credit is for state death taxes paid. The maximum credit is determined according to a rate schedule based upon the adjusted taxable estate. The credit ranges from zero to 16 percent; the full rate schedule is shown in Table 2. The credit acts to reduce the maximum federal marginal estate tax rate from its statutory rate of 55 percent to 39 percent. However, the operation of the credit does not affect either the total (state plus federal) tax liability or overall marginal tax rate that an estate faces. Each $\$ 1$ credit issued by the Federal government is offset by $\$ 1$ in state level estate taxes paid. Credits also exist for prior federal and state gift (and estate) taxes paid. $^{16}$

State-level death taxes take two forms. States tax either the action of bequeathing (an estate tax) or the receipt of proceeds from an estate (an inheritance tax). From a public finance perspective, the decision to tax the estate versus the inheritance is simply a choice concerning the statutory incidence. As usual, the economic effects are not a function of such statutory decisions. 
Every state has a tax that is exactly equal to the federal credit for state estate taxes. This sponge (or "pick-up") tax is simply a transfer of tax revenue from the federal government to the states. However, in 199218 states had estate taxes that potentially exceeded the maximum credit and, thus, added to the overall tax liability. ${ }^{17}$ Three of these "non-sponge" states employ an estate tax; 15 rely on an inheritance tax. ${ }^{18}$ Marginal tax rates for the former range from 0 percent to 21 percent and for the latter from 0 percent to 30 percent. The key issue - whether these taxes carry levies greater than the size of the federal credit and, thus, increase total estate tax liabilities - depends upon the size of the estate and/or the size and composition of bequests.

Table 3 displays the effects of the Federal unified credit, the credit for state death taxes, and conveys the difference in marginal tax rates from living in a non-sponge tax state. The key feature of the table is the final column, which shows two important features of the overall tax system. First, living in a non-sponge state generates a marginal death tax in excess of that in a sponge tax state. In what follows, we will use this geographic variation as a key to identifying behavioral responses.

Second, the bulk of the marginal effects occur at relatively low levels of wealth. Thus, one would expect to observe an impact of the estate tax on individuals well below the wealth levels of the "super rich." From a research perspective, this is fortuitous. The super rich are, by definition, rare and unusual. In contrast, the "mere mortals" identified in Table 3 occur in more substantial numbers and are, thus, amenable to analysis using the typical statistical methods. This is our strategy below.

To gain a feel for the institutions, consider a single individual near the median level of wealth $(\$ 200,000)$ who dies in Florida. Florida is typical of sponge tax states in that its levy is equal to the federal credit, and sets its filing requirements equal to the federal amounts. Thus, an individual dying in Florida would have no net estate tax burden either due to the credit or, in this 
case, because they would not be required to file. In contrast, if the same individual died as a resident of New York, she would face a state estate tax liability of $\$ 6,000$. This would not be offset by a federal credit because the individual is below the federal filing threshold of $\$ 600,000$. In short, an individual with wealth well below the federal estate tax threshold is potentially subject to a substantial estate tax levy as a resident of a non-sponge tax state.

\subsection{The Health and Retirement Study}

The analytic framework outlined above suggests that it is useful to focus on those individuals who are far enough along in the life cycle to realistically contemplate saving, bequest, and estate tax considerations. However, they must be young enough to permit behavioral responses to incentives provided by the tax system.

The Health and Retirement Study (HRS) is a nationally representative sample of the older working age population, a group that is more likely to be cognizant of estate tax issues. The HRS began in 1992 with a random sample of non-institutionalized men and women aged 51 to 61 and their families. Respondents outside of this age range appear only if their spouse is an age-eligible respondent. Re-interviews have occurred every two years. Currently, four waves of information are available in public release; this paper makes use of the first wave. ${ }^{19}$ The baseline survey contains 12,652 respondents from 7,607 households, including an over-sample of blacks, Hispanics, and residents of the state of Florida. A more detailed discussion of the HRS can be found in Juster and Suzman [1995].

A key feature of the empirical strategy is the use of geographic information. In addition to public release HRS data, we use restricted access "Geocode" information on the respondent's state of birth and state of residence. Of course, the HRS does not contain data on taxes. Thus, we employ the National Bureau of Economic Research's Internet TAXSIM program to generate 
federal and state income tax liabilities for HRS respondents. ${ }^{20}$ We are forced, however, to generate our own estimates of the estate tax liabilities and marginal incentives, a task to which we now turn.

\subsection{Estate Tax Calculators}

We construct separate tax calculators for the federal estate tax and each of the 50 state death taxes. ${ }^{21}$ The tax base is equal to the sum of housing equity, certificates of deposits, checking accounts, savings accounts, business equity, stocks, bonds, mutual funds, defined contribution pension wealth plus the value of all life insurance policies minus appropriate deductions. $^{22}$ The inclusion of defined contribution pension wealth assumes that all defined contribution pension plans require a lump-sum distribution, thus transforming it into bequeathable wealth. The tax liability is found by applying the appropriate tax schedule. Statutory federal marginal rates range from 37 percent to 55 percent and statutory state marginal rates range from 0 percent to 21 percent.

For those states with inheritance taxes, we impute the distribution of estates to heirs as inheritance tax liabilities depend upon the expected dispersal pattern, based on the 1982 Collation study conducted by the Statistics of Income Division of the Internal Revenue Service.

In the context of the model, individuals respond to the expected estate tax. Unlike the simple two-period framework, however, individuals' life expectancies differ for a multitude of reasons, including age, race, gender and wealth. We convert the statutory rate determined by our tax calculator into a forward-looking, expected estate tax rate. For each individual, we calculate the wealth-adjusted probability that the individual will die, and thus realize their estate tax liability in the particular year. ${ }^{23}$ The present value of these values determines the expected estate tax liability. Marginal tax rates are computed in an analogous fashion. 
This calculator is quite crude, but the amount of measurement error that this creates is uncertain. In particular, the estate tax calculator does not take into account potential future estate tax-minimizing behavior or life-cycle asset decumulation. ${ }^{24}$ While there are many ways to reduce estate tax liabilities, Poterba's [1997, 1998] results suggested that many individuals fail to capitalize on opportunities to reduce estate taxes.

To check the accuracy of the estate tax calculator, we compare its predicted total estate tax collections with actual estate tax receipts. To do so, we take advantage of independent information in the Study of Assets and Health Dynamics Among the Oldest Old (AHEAD). The AHEAD has a survey structure nearly identical to the HRS, allowing us to apply the estate tax calculator. As reported in Marples [2000], the average estate tax per taxable estate in the AHEAD was $\$ 350,240$, which is very close to the actual value of $\$ 385,706$ reported in Joulfaian [1998] Table 7.

\section{ESTIMATING BEHAVIORAL ELASTICITIES}

\subsection{Wealth Accumulation, Capital Income Taxes, and the Estate Tax}

We begin putting some empirical flesh on our analytic skeleton by estimating the elasticity of wealth accumulation with respect to the estate tax $\left(\varepsilon_{W B}\right.$, above). As the previous section makes clear, however, the elasticity of wealth accumulation with respect to the estate tax should be analyzed in the same framework as the elasticity of accumulation with respect to capital income taxes ( $\varepsilon_{W 1}$, above). Hence, this is our basic strategy in what follows.

We begin by regressing the logarithm of net worth on the fundamental determinants of wealth accumulation. ${ }^{25}$ That is, we seek to control for the cumulative difference between earnings and outlays. Specifically, we control for the position in the life cycle using age (Age) and age-squared (Age Squared). We proxy for overall consumption demands during the life 
cycle by a dummy variable for the presence of children (Have Children). (Using instead the number of children has no substantive effect on the remainder of the analysis.) We capture the ability to generate labor earnings using indicator variables for educational attainment (High School, College), gender (Female), and race (Black, Non-Black Non-White).

Of course, the rate at which individuals are willing to accumulate assets depends upon their time horizon. We capture heterogeneity in this aspect by including the self-assessed probability of living to age 75 (Live to 75 ) and to age 85 (Live to 85).

Finally, there are extraordinary events on both sides of the wealth accumulation balance. On the expenditure side, we control for the outlays associated with poor health by a series of indicator variables for health status (Excellent, Very Good, Fair, Poor), changes in health status (Much Better, Better, Worse, Much Worse), and a previous divorce (Divorced). On the receipts side, we include an indicator variable for the past receipt of an inheritance (Received Inheritance).

To complete our regression specification, we include on the right side the two tax variables - estate and income - each of which is entered as the logarithm of the ad valorem form dictated by our analytic framework. Specifically, we include $\ln \left(1+\mu_{1}\right)$ and $\ln \left(1+\mu_{B}\right)$, where $\mu_{1}$ is computed as $\frac{r \theta}{1+r(1-\theta)}$. We assume that $r=0.096 . \theta$ is the individual's marginal income tax rate-inclusive of state-level income taxes — as computed by TAXSIM. Similarly $\mu_{B}=\frac{\tau}{1-\tau}$, where $\tau$ is the expected present value estate tax rate from our calculation. Two aspects of this specification merit note. First, we choose our specification to be consistent with our goal of utilizing equation (20). Second, we place the estate tax and capital income tax on equal footing by computing the present value tax on one dollar of assets. 
To begin, we show the ordinary least squares estimates of the parameters in column 1 of Table 5. (Descriptive statistics of all variables used in the analysis are shown in Table 4.) Our focus is on the tax variables. As shown in rows two and three, the estimated coefficient for the estate tax variables is 24.4 , and is statistically significant, while the coefficient for the capital income tax variable is also positive (3.05) and statistically significant. ${ }^{26}$

While useful for providing a benchmark, the OLS parameter estimates of the elasticities are likely contaminated by several sources of bias. Hence, we turn now to constructing instrumental variables estimates of the key elasticities. We begin with the estate tax. The key, of course, is to identify an exogenous source of variation in estate tax incentives. In this instance, all individuals face the same Federal estate tax incentives, so our strategy is to exploit the statelevel variation in transfer taxes to identify our parameters. Unfortunately, merely using the statespecific marginal estate tax rate is unlikely to suffice. Thus, we construct our instrumental variables in the following steps:

1. State of birth. Individuals' state-level marginal tax rates are determined by whether they choose to locate in a sponge tax state or not. Ceteris paribus, one might anticipate that high-wealth individuals would choose low-tax states. Our solution is to evaluate the individual's state-level estate tax in the state of birth, as opposed to the state of residence.

2. Fixed, Exogenous Wealth Levels. At the state (and federal) level, estate taxes and wealth accumulation are determined simultaneously. Ceteris paribus higher levels of wealth are automatically associated with higher estate tax rates. To break this link, we evaluate the estate tax at exogenous levels of wealth. Specifically, we compute five tax rates for each individual, with the tax rates computed using the wealth level at the $10^{\text {th }}$ percentile, $25^{\text {th }}$ percentile, median, $75^{\text {th }}$ percentile, and $90^{\text {th }}$ percentile of the wealth distribution in the sample.

3. Fixed, Exogenous Demographic Characteristics. Our present-value marginal estate tax rate is computed using wealth-adjusted mortality probabilities. To eliminate the specter of simultaneous determination of wealth and mortality probabilities, we compute each of the five instrumental variable tax rates using fixed demographic characteristics. Specifically, we compute the tax rate assuming that every individual is a white male aged 56 in 1992. 
The upshot of this approach is that we rely for identification on the exogeneity of the state of birth and the state-by-state variation in the shape of the estate tax schedule.

A similar set of considerations arise in the context of the income tax-individuals may locate based on tax considerations, the marginal tax rate is determined simultaneously with capital income (and thus wealth), and so forth. Hence, we construct individual-specific instrumental variables for the capital income tax in analogous steps. We compute the instrumental variables using the individual's state of birth at fixed points $\left(10^{\text {th }}, 25^{\text {th }}, 50^{\text {th }}, 75^{\text {th }}\right.$, and $90^{\text {th }}$ percentiles) of the taxable income distribution.

Column 2 of Table 5 shows the estimates derived using our instrumental variable procedures. Before turning to the tax variables, an inspection of the other covariates indicates that they are consistent with a sensible picture of the profile of wealth accumulation. Wealth rises with age, higher education, excellent and very good health, and the receipt of inheritance. It declines with the presence of children, minority status, and fair or poor health. Not all the coefficients are estimated precisely and some anomalous results are present (e.g. the positive coefficient on Female), but the overall performance of the specification seems reasonable.

Our primary interest is on the estimated coefficients for the tax variables. As shown in row 2, after controlling for the various possible biases the estimated impact of the estate tax is negative (-37.8) and statistically significant. Notice also that, as the model predicts, the impact of income taxes is not identical; the estimated coefficient is negative $(-3.75)$, but statistically insignificant. Again, to gauge magnitudes, the former estimate is comparable to an elasticity with respect to the estate tax rate of roughly -1.4 , while the latter is equivalent to a tax-rate elasticity of roughly -0.04 . Put differently, our estimates of the role of capital income taxation are consistent with the literature that finds little effect of after-tax returns on saving, giving us some confidence regarding the (more substantial) estimated estate tax coefficient. 
Our basic findings suggest that capital taxes have a modestly depressing effect on the accumulation of wealth. Given that there are limited precedents in the literature, especially for the estate tax, it is desirable to check the robustness of our finding. One possibility, for example, is that our estimated coefficient is contaminated by spurious correlations with omitted nonlinearities with respect to demographic groups that reflect, for example, underlying tastes or mortality probabilities. To investigate this, we augmented our basic specification with dummy variables representing 20 combinations of age, race, and gender. ${ }^{27}$ This specification provides a flexible control for such omitted effects. As shown in the first row of Table 6, the basic character of our results is unchanged. The estimated coefficient for the estate tax is -39.1 , while the capital income tax coefficient is estimated to be -3.56 , although in both instances the estimated precision of our estimates is a bit lower.

Another possibility is that our use of state-by-state variation runs the risk of being confounded by underlying differences among states per se. A direct approach to addressing this issue is to directly include state dummy variables, although the presence of these controls reduced the variation available to identifying our parameters. As shown in the second row of the table, including dummy variables for each state reduces the estimated coefficient for the estate tax to -14.8 (with a standard error of 12.4), while the capital income coefficient changes substantially. Of course, as noted, the inclusion of state-specific dummy variables leaves less identifying variation, so the decline in precision is perhaps unsurprising. To push this line of investigation to its logical limit, we show in the third row the estimates that result when we include by types of controls. These are quite similar to those containing only the state dummy variables.

Another possibility is that our specification is overly restrictive in that it assumes that the effect of the estate tax is the same for those individuals with and without children. In contrast, it 
is sometimes assumed that the presence of a child is a proxy for a bequest motive. If so, the effect of the estate tax on wealth accumulation (which operates via the assumed desire to leave a bequest) will differ between groups. The next row of Table 6 shows the impact of adding to our basic specification a variable which is the interaction of Have Children and the estate tax variable. Inclusion of the interactive variable lowers the estimated coefficient from -39.1 in row 1 to -18.4 (with a standard error of 6.70 ). From this perspective, the estate tax continues to have a negative effect on wealth accumulation. The coefficient on the interaction variable itself is -2.73 , with a substantial amount of imprecision.

Our final two specification checks address the functional form for the tax rate variables. While our specification follows directly from our derivation of deadweight loss, two other specifications are quite common in the empirical literature on the effects of taxation. Row five of the table shows the impact of a "tax price" specification in which the estate tax is captured by the natural logarithm of its tax price-defined to be 1 minus the marginal tax rate. (The capital income tax variable is defined analogously.) As shown, as the estate tax price rises, wealth accumulation is augmented, although the coefficient is not precisely estimated.

The last line of the tables shows the effect of entering the marginal tax rates directly into our estimating equation. As the table makes clear, the negative relationship between estate taxes and wealth accumulation — corrected for a myriad of potential endogeneity biases - is not an artifact of the particulars of the specification.

To summarize, in a wide variety of settings we find a negative relationship between wealth accumulation and the estate tax, although the statistical precision of the estimates varies somewhat. For the capital income tax variable, we estimate coefficients of widely varying sign, size, and precision. As described earlier, these two elasticities are central to the efficiency 
properties of alternative approaches to taxing capital income. The remaining issue is the impact of taxes on the amount of desired bequests, a topic to which we now turn.

\subsection{Desired Bequests and Capital Taxes}

The next key behavioral parameter is the elasticity of bequests with respect to the estate $\operatorname{tax}\left(\varepsilon_{B B}\right.$, above $)$. In contrast to the previous section, however, there is a bit of guidance from extant literature regarding the size of this effect. Kopczuk [2000, fn. 31] reports that the estimates of Kopczuk and Slemrod [2000] imply an elasticity of bequests with respect to the marginal estate tax rate of between -0.4 and -0.7 . In the context of our model, this corresponds to an elasticity with respect to our ad valorem estate tax variable of between -11.4 and -19.9.

Are these magnitudes plausible? Unfortunately, our data do not contain information on the dollar value of actual, or even desired, bequests. However, the HRS does contain information regarding the desires of individuals to leave bequests. Specifically, we construct a dummy variable that equals 1.0 if the individual feels that it is "important" or "very important" to leave a bequest, and 0 otherwise. ${ }^{28}$

How do capital taxes affect the desire to leave a bequest? Building on our analysis of wealth accumulation in the previous section, we structure our analysis in the following steps. First, in column 1 of Table 7 we display the ordinary least squares estimates of a linear probability model in which the dependent variable is the indicator variable for a desired bequest, and the covariates are identical to those used in our investigation of wealth accumulation. Our focus is on the effect of taxes; as shown the OLS estimate of the estate tax is positive, while that of the capital income tax is negative. However, there is little reason to dwell on these estimates, or those of the other covariates. As we outlined above, we have reason to suspect that the OLS estimate is subject to a variety of biases. Hence, we employ our instrumental-variables 
procedure to estimate the impact of the estate tax and the capital income tax on the probability of leaving a bequest.

The second column shows the estimates from our instrumental variables procedure. Before turning to the tax variables, we note only that the probability of having a desired bequest rises with age, having children, female or minority status, education, having received an inheritance, or being divorced. Health and health changes have a mixed impact. We leave an extensive inspection on these covariates to the reader.

Instead, we focus on the results for the tax variables. As shown, the parameter estimate for the estate tax is -8.48 , with a standard error of 4.33 , while that for the capital income tax remains negative (-2.76) and imprecisely estimated. That is, both taxes lower the probability of wanting to leave a bequest. While far from perfect estimates of the parameter of interest, the results are sufficiently interesting to be pursued in two ways.

First, we impose a bit more structure on the estimates by assuming that the error term follows a normal distribution, thus yielding the probit statistical model. The instrumentalvariables probit estimates are shown in the final column of Table 7. We follow the recommendation of Blundell and Powell [2000] and control for endogeneity by including the actual tax variable and the estimated residual from our first stage regressions (the "control function" approach in their terminology). This provides us with both a direct test for endogeneity bias — the t-statistic on the included residual—and consistent estimates of the parameters of interest.

Looking first at the coefficients on the estimated residuals indicates that qualitatively endogeneity bias is an important issue, i.e., the variables are significant. Also, as a quantitative matter, the bias is positive. For the estate tax, the instrumental variable approach yields an estimate of -23.3 (with a standard error of 10.7). ${ }^{29}$ In the context of the model (especially the 
probit model), we can interpret the coefficients in columns 2 and 3 as the parameters of an unobserved linear index determining the size of the desired bequest; i.e. when the desired index crosses a threshold the individual reports wanting to leave a bequest.

This is useful, as we need to quantify the impact of anticipated estate taxes on desired bequests. From this perspective, the coefficient sheds light on this behavioral response. Given our specification, the coefficient is the estimate of the level of the desired bequest with respect to the logarithm of the estate tax variable. We can convert this to an elasticity estimate by dividing by the predicted value of the desired bequest at the sample means. Using the smaller of the two estimates $(-8.48)$ to err on the conservative side, the resulting elasticity is roughly -13 . When converted to an elasticity with respect to the expected estate tax rate, the result is about $-0.5-$ remarkably close to the estimate of Kopczuk and Slemrod.

Of course, it is sensible to conduct a set of robustness checks on our parameter estimate in parallel to that which we presented regarding the accumulation of net worth. Doing so yields a pattern of results reminiscent of our discussion of the wealth accumulation estimates, above. Specifically, as shown in Table 8, the inclusion of direct control for demographics has essentially no effect on the estimates. The same broad conclusion holds for the inclusion of an interaction with More Children, as well as choosing alternative functional forms for the tax variables.

In contrast, the inclusion of the state dummy variables, either in isolation or in conjunction with the demographic controls, reduces significantly both the magnitude and the statistical precision of the estimated impact of taxes.

\section{DEADWEIGHT LOSS AND ESTATE TAX REFORM}

In this section, we draw together the implications of our estimates for the efficiency consequences of replacing the estate tax with an equal-yield capital income tax. ${ }^{30}$ That is, we 
evaluate equation (20) under a variety of "scenarios." To do so, we must evaluate the formula for each individual, which requires us to choose values for the bequest share in wealth $\left(B / W_{1}\right)$ and our three elasticities.

Consider first the possible values of the bequest share. As noted above, the conceptual experiment is "what fraction of my late-life wealth do I wish to pass (unsheltered) to my children?" Clearly, our data do not contain the answer to this piece of introspection. One strategy is to use estimates from the literature help us to obtain a rough gauge of the appropriate range of values. As reported in Eller et al. [2000], Wolff [1995] estimated using the Survey of Consumer Finances that estate tax collections in 1990 should be roughly $\$ 44$ billion, compared with actual collections of $\$ 10.3$ billion. If the estate tax were linear, the former number would represent $\tau W_{1}$, while the latter is $\tau B$. In the simplest setting, the ratio is an estimate of the bequest share. In this case, it suggests a value of roughly one-quarter. Unfortunately, using similar techniques based on Poterba [1997], Eller et al. [2000] estimate that the ratio of actual to predicted collections is nearly 0.90 . Clearly the range is too large to be terribly useful.

Moreover, it is quite possible that a significant portion of actual estates represent unintended bequests by life-cycle savers. (See Hurd and Smith [2000] for evidence.) In the context of the model, the bequest share is the fraction of intended bequests in late-life wealth accumulation. With the goal of choosing a conservative value, we set the bequest share at 10 percent. This is less than one-half of the lower-bound estimate above, and consistent with the findings of Hurd and Smith that the likelihood of substantial estates falls with age.

We begin our investigation by taking at "face value" the basic instrumental variables estimates of our other parameters. That is, we compute the estate tax elasticity and income tax elasticity using the coefficients ( -37.8 and -3.8 , respectively) in column 2 of Table 5 , and the bequest elasticity using the coefficient (-8.5) in column 2 of Table 7, which implies an elasticity 
of -13.1 . Using these parameter values, we estimate the efficiency gain from replacing the estate tax for each individual in our sample.

Rather than report a single value, we show in Figure 1 the efficiency gain at each point in the wealth distribution in the sample. Looking at Figure 1 yields several lessons. First, the efficiency consequences are centered near zero, with a modest tendency toward efficiency gains. Second, there is no particular tendency for gains to accrue to the affluent, or vice-versa. Instead, the efficiency gains and losses (per dollar of wealth) appear equally distributed along the wealth distribution. Finally, there are significant outliers will affect any single measure of the central tendency of the efficiency gains. ${ }^{31}$

To focus the discussion, we take three steps. First, in the interests of interpreting our estimates modestly, and erring on the side of conservative estimates, we set the "baseline" value of each elasticity equal to one-half of the estimated values. Second, for purposes of graphical presentation only, we trim from the observations those values that are more than two standard deviations above or below the mean. This precludes having the outliers dominate the presentation. Finally, we check the sensitivity of our estimates to our assumptions regarding the elasticities.

To see the results, consider first Figure 2, which focuses on the effect of the estimated bequest elasticity. The middle line shows the distribution of the baseline estimates of the efficiency gains. The mean value is 0.069 , while the median is 0.009 . The latter indicates an efficiency gain of $\$ 9$ for each $\$ 1,000$ of wealth accumulation, while the former implies $\$ 69$. The dashed lines shows the effect on the distribution of doubling the baseline estimate of the elasticity of bequests with respect to the estate tax variables $\left(\varepsilon_{B B}\right)$, while the dotted line shows the impact of setting the elasticity equal to zero. As the figure makes clear, these variations have little impact on the distribution of the efficiency effects, with the only noticeable impact in the 
upper tail of the distribution. In the "low elasticity" scenario, the mean falls to $\$ 0.034$, while the median becomes zero. In the "high elasticity" version, the mean rises to $\$ 0.108$, while the median remains $\$ 0.009$.

Figure 3 displays the corresponding computations with respect to the impact on wealth accumulation of estate taxes $\left(\varepsilon_{W B}\right)$. As in Figure 2, the estimate of the central portion of the distribution is not especially sensitive to changes in the elasticity. However, in this instance the tails are more noticeably altered. Lowering the elasticity to zero reduces the mean efficiency gain to $\$ 0.022$, but raises the median to $\$ 0.017$. Using the higher elasticity leaves the median unchanged from the baseline $(\$ 0.009)$, but raises the mean to $\$ 0.12$.

Finally, Figure 4 displays the computations with respect to the impact on wealth accumulation of income taxes $\left(\varepsilon_{W 1}\right)$. Again, the tails show sensitivity to the chosen value, but the central portion of the distribution remains unchanged. Here, using the low elasticity reduces the mean from an efficiency gain to an efficiency loss of $\$ 0.094$, but leaves the median unchanged. Using the higher elasticity leaves the median unchanged from the baseline (\$0.009), but raises the mean to $\$ 0.29$.

Taken as a whole, and focusing on the medians as the estimate of central tendency, our estimates suggest an efficiency gain of roughly $\$ 0.01$ to $\$ 0.02$ per dollar of wealth to eliminating the estate tax and replacing it with a capital income tax. Of course, this computation is about the differential excess burden, and is silent regarding the level of the deadweight cost. In this light, it is interesting to note that Feldstein [1978] uses a similar analytic framework to analyze the distortion cost of taxing capital income. He concludes that the excess burden is comparable to the sectoral misallocation stemming from the corporation income tax. Our findings suggest that the estate tax has effects comparable to both in magnitude. In our eyes, this is intriguing as our 
estimates are based on data that do not contain the "super-rich" who are likely most highly affected by the estate tax.

\section{6. $\underline{\text { SUMMARY }}$}

We have sought to develop a framework to analyze the efficiency consequences of the estate tax that is relatively parsimonious with respect to the empirical information required. In addition, we have presented new evidence that the estate tax reduces capital accumulation and desired bequests. Combining these estimates with modest impacts of after-tax interest rates on saving, yields estimates of a modest efficiency gain in replacing the estate tax with a capital income tax. Put differently, the efficiency cost of the estate tax is a bit greater than that of the tax on capital income. Because our estimates are based on data that do not contain the highly affluent who are most highly affected by the estate tax, this suggests substantial burdens that merit additional study. ${ }^{32}$ 


\section{ENDNOTES}

1. Interest in consumption-based systems is generally traced to Blueprints for Basic Tax Reform (U.S. Treasury [1977]). In some cases, the focus is on "flat" taxes; see, especially, Hall and Rabushka [1995].

2. Our presentation assumes that all capital income is taxed at a single rate. Obviously this is a far cry from the reality of capital income taxation in the United States. In practice, $\theta$ is best thought of as a weighted average effective tax rate on capital income (including accrued capital gains).

3. We make the simplifying assumption that all transfers occur at death. In practice, the estate tax is one component of a unified transfer tax that distorts the relative price of inter vivos giving and bequests (see Joulfaian [2000]). The contribution of this distortion to the overall deadweight loss is a useful area for future research.

4. See Schmalbeck [2000] for an extensive discussion of these techniques. Note that our specification of avoidance abstracts from any fixed costs that are required to set up an avoidance scheme, and focuses instead on marginal changes in the scale of the avoidance.

5. An assumption implicit in our formulation is that funds devoted to avoidance of the estate $\operatorname{tax}(A)$ do not avoid the capital income tax. To the extent that they do, the effective value of $\theta$ is lower still.

6. Our analysis is partial equilibrium in nature and does not consider the impact of the tax system on wages and rates of return.

7 Marples [2000] provides evidence that the estate tax lowers the labor force participation of older workers. This suggests that incorporating labor supply decisions is a useful area of future research, but is beyond the scope of the current paper.

8. Of course, the current policy debate focuses on lowering $\mu_{B}$. Hence, we conduct our efficiency analysis in terms of reducing $\mu_{B}$ and raising $\mu_{1}$.

9. Our derivative does not depend on why the household leaves a bequest. It assumes only that bequests are non-zero and a source of utility. Many analysts focus of the effect of estate taxes on, for example, saving. For that purpose, it is important to understand bequest motives. (See, for example, Gale and Perozek [2000].) The traditional analysis of deadweight loss, however, respects households' motivations for economic activity, and focuses on the tax-based alteration in the means to reaching their objectives.

10. For this calculation we continue to assume that $r=0.08, \tau=0.035$, and $\theta=0.10$. 
11. In light of the continuing controversy of the difficulties of administering the estate tax, it is interesting to note that the estate tax was originally chosen over an inheritance tax because of its perceived administrative simplicity.

12. The Economic Recovery Tax Act of 1981 (ERTA) added to the gross estate life insurance policies that switched ownership in the three years prior to death.

13. The are several departures from the principle of using "market value" to determine the gross estate. See Marples [2000] for a summary.

14. As noted by Joulfaian [2000], this treatment does not precisely equalize the rate of taxation of bequests at death and gifts during life.

15. The effective exemption in 1998 was $\$ 625,000$ and $\$ 650,000$ in 1999 . For $2000-2001$ the effective exemption is $\$ 675,000$. This rises to $\$ 700,000$ for $2002-2003, \$ 850,000$ in 2004, \$950,000 in 2005 and $\$ 1,000,000$ in 2006 and thereafter.

16. To minimize undue taxation of recently inherited wealth, a credit is allowed for the estate taxes paid on a recent inheritance. This credit is phased out over ten years, in two-year increments.

17. The states are Delaware, Iowa, Kentucky, Louisiana, Maryland, Massachusetts, Michigan, Mississippi, Montana, New Jersey, New York, North Carolina, Oklahoma, Pennsylvania, South Dakota, Tennessee, Rhode Island, and Connecticut.

18. Mississippi, New York and Massachusetts have state level estate taxes.

19. Despite the fact that the HRS provides panel data, we focus on cross-sectional analysis. This is dictated by the fact that there was no change in estate tax laws during the sample period, thus providing no inter-temporal variation to exploit.

20. Computation of income tax liabilities requires the submission of 18 variables commonly found in non-tax surveys. These variables are an id number, tax year, state of residence, martial status, number of dependents, age exemptions, wage and salary of the taxpayer (set equal to zero), wage and salary of the spouse, dividend income, other property income, pensions, gross social security, other transfer income, rent paid, itemized deductions, child care expenses and unemployment compensation. The HRS contains all of these variables, with the exception of information regarding the dollar value of itemization. Since the accuracy of TAXSIM increases, this variable is imputed using the results of Bruce [1999]. A detailed discussion of the TAXSIM model can be found in Feenberg and Coutts [1993].

21. These calculators are based on Marples [2000] and are described more fully therein.

22. In 1992 , these deductions totaled $\$ 600,000$ per person and $\$ 1,200,000$ per couple for Federal Taxes. These figures are currently $\$ 675,000$ per person and $\$ 1,350,000$ per 
couple. They are scheduled to increase to $\$ 1,000,000$ per person and $\$ 2,000,000$ by 2006.

23. The probabilities of death used from the U.S. Census Bureau [1999] and Social Security Administration [1992]. These tables allow for delineation based upon age, race and gender. Adjustments based upon wealth levels are derived from Attanasio and Hoynes [2000].

24. In principle, we could impute to each household a profile of accumulation and decumulation. In practice, we rely on cross-sectional variation to identify our parameters, and any such temporal imputation would introduce substantial arbitrariness to little benefit.

25. The correspondence between net wealth as measured in the HRS and $W_{1}$ in our theoretical model is not exact. We have no information, for example, on the value of Social Security wealth on defined-benefit pension plans.

26. Recall from above, that one should interpret the magnitude of the coefficient in the context of the model. The estimates corresponds to an elasticity with respect to the estate tax of 0.88 and an elasticity with respect to the income tax rate of 0.04 (computed using the mean effective estate tax rate $(0.035)$, income tax rate $(0.164)$, and a rate of return of 9.6 percent).

27. Specifically, the variables are for the groups representing combinations of gender (male, female), race (black, non-black), and age (51-52, 53-54, 55-56, 57-58, 59-61) groups.

28. We also experimented with a variable that is equal to 1.0 only if the individual feels it is "very important" to leave a bequest. Our qualitative results are unchanged by this choice, although the statistical significance a bit lower. The latter result likely reflects the lower rate of positive responses.

29. We estimate the standard errors via a design-matrix bootstrap procedure (see Buchinsky [1995]) using 250 bootstrap replications.

30. To be precise, we evaluate the deadweight loss implications of a marginal reduction in the estate tax rate along with an equal yield marginal increase in the capital income tax rate. We thus hold fixed all non-tax-rate aspects of both systems; e.g., the enforcement regime.

31. The presence of outliers may simply reflect that equation (20) is a linear approximation, and for some individuals the quality of the approximation may be quite low.

32. It is possible, of course, that the super rich respond less elastically than the remainder of the population. For example, they may simply be quite driven and use money to "keep score." We thank Roberton Williams for emphasizing this point. 


\section{REFERENCES}

Attanasio, Orazio P. and Hillary W. Hoynes. 2000. " Differential Mortality and Wealth Accumulation,” Journal of Human Resources, 35(1) (Winter): 29.

Auten, Gerald and David Joulfaian. 2000. "Bequest Taxes and Capital Gains Realizations," unpublished manuscript Office of Tax Analysis. Washington, DC: U.S. Department of the Treasury, February.

Blundell, Richard and James Powell. 2000. "Endogeneity in Nonparametric and Semiparametric Regression Models," unpublished manuscript. London: University College.

Bruce, Donald. 1999. "Effects of the United States Tax System on Transitions into SelfEmployment," unpublished manuscript, Center for Policy Research, The Maxwell School. Syracuse, NY: Syracuse University.

Buchinsky, Moshe. 1995. "Estimating the Asymptotic Covariance Matrix for Quantile Regression Models: A Monte Carlo Study," Journal of Econometrics, 68(2): 303-338.

Eller, Martha Britton, Brian Erard, and Chih-Chin Ho. 2000. "The Magnitude and Determinants of Federal Estate Tax Compliance." Prepared for Rethinking Estate and Gift Taxation, Brooking Institute, May 2000.

Feenberg, Daniel R. and Elizabeth Coutts. 1993. "An Introduction to the TAXSIM Model," Journal of Policy Analysis and Management, 12(1) (Winter): 189-194.

Feldstein. Martin. 1978. "The Welfare Cost of Capital Income Taxation," Journal of Political Economy, 86(2) (April).

Gale, William, and Maria Perozek. 2000. "Do Estate Taxes Reduce Saving?” Prepared for Rethinking Estate and Gift Taxation, Brooking Institute, May 2000.

Hall, Robert and Alvin Rabushka. 1995. The Flat Tax, 2nd Edition. Stanford, CA: The Hoover Institution Press.

Hurd, Michael and James P. Smith. 1999. "Anticipated and Actual Bequests," NBER Working Paper No. W7380. Cambridge, MA: National Bureau for Economic Research, October.

Joulfaian, David. 1998. "The Federal Estate and Gift Tax: Description, Profile of Taxpayers, and Economic Consequences," Office of Tax Analysis Paper 80. Washington, DC: U.S. Department of the Treasury, December.

Joulfaian, David. 2000. "Charitable Giving in Life and Death." Prepared for Rethinking Estate and Gift Taxation, Brookings Institute, May 2000. 
Juster, F. Thomas and Richard Suzman. 1995. "An Overview of the Health and Retirement Study," Journal of Human Resources, 30: S7-S56.

Kopczuk, Wojciech. 2000. “The Trick is to Live: Is the Estate Tax Social Security for the Rich?" unpublished manuscript, Department of Economics. Ann Arbor: University of Michigan.

Kopczuk, Wojciech and Joel Slemrod. 2000. "The Impact of the Estate Tax on Wealth Accumulation and Avoidance Behavior of Donors." Prepared for Rethinking Estate and Gift Taxation, Brookings Institute, May 2000.

Marples, Donald. 2000. "Labor Supply Effects of the Estate Tax," unpublished manuscript, Center for Policy Research, The Maxwell School. Syracuse, NY: Syracuse University.

McGarry, Kathleen. 1999. "The Cost of Equality: Unequal Bequests and Tax Avoidance," unpublished manuscript, Department of Economics. Los Angeles: University of California, February.

McGarry, Kathleen. 1999. "Inter vivos Transfers or Bequests Estate Taxes and the Timing of Parental Giving," unpublished manuscript, Department of Economics. Los Angeles: University of California, November.

Poterba, James. 1997. “The Estate Tax and After-Tax Investment,” NBER Working Paper No. 6337. Cambridge, MA: National Bureau of Economic Research, December.

Poterba, James. 1998. "Estate and Gift Taxes and Incentives for Inter Vivos Giving in the United States," NBER Working Paper No. 6842. Cambridge, MA: National Bureau of Economic Research, December.

Schmalbeck, Richard. 2000. “Avoiding Federal Wealth Transfer Taxes.” Prepared for Rethinking Estate and Gift Taxation, Brooking Institute, May 2000.

Social Security Administration. 1992. "Life Tables for the Social Security Area 1900-2080," Actuarial Study No. 107. Social Security Publication No. 11-11536. Washington, DC: Social Security Administration, August.

United State Census Bureau. 2000. "Population Projections of the United States, 1999 to 2100," Population Division. Washington, DC: Government Printing Office, January.

U.S. Treasury. 1977. Blueprints for Basic Tax Reform. Washington, DC: U.S. Department of the Treasury. Reprinted in 1984 by Arlington, VA: Tax Analysts.

Wolff, Edward. 1995. "The Rich Get Increasingly Richer: Latest Data on Household Wealth During the 1980s," Research in Politics and Society, 5: 33-68. 
Table 1. Federal Estate Tax:

Marginal Tax Rates

\begin{tabular}{rrc}
\hline \multicolumn{2}{c}{$\begin{array}{c}\text { Adjusted Taxable Estate } \\
(\$ 1,000 \mathrm{~s})\end{array}$} & $\begin{array}{c}\text { Federal Marginal } \\
\text { Tax Rate } \\
\text { (percent) }\end{array}$ \\
\hline Over & But less than & 18.0 \\
10 & 10 & 20.0 \\
20 & 20 & 22.0 \\
40 & 40 & 24.0 \\
60 & 60 & 26.0 \\
80 & 80 & 28.0 \\
100 & 100 & 30.0 \\
150 & 150 & 32.0 \\
250 & 250 & 34.0 \\
500 & 500 & 37.0 \\
750 & 750 & 39.0 \\
1,000 & 1,000 & 41.0 \\
1,250 & 1,250 & 43.0 \\
1,500 & 1,500 & 45.0 \\
2,000 & 2,000 & 49.0 \\
2,500 & 2,500 & 53.0 \\
3,000 & 3,000 & 55.0 \\
\hline
\end{tabular}

${ }^{a}$ The adjusted taxable estate is equal to the taxable estate minus $\$ 60,000$.

Source: Internal Revenue Service Estate Tax Code. 
Table 2. Federal State Death Tax Credit

Schedule: 1992

\begin{tabular}{|c|c|c|c|c|}
\hline \multicolumn{2}{|c|}{$\begin{array}{l}\text { Adjusted Taxable Estate }^{\mathrm{a}} \\
(\$ 1,000 \mathrm{~s})\end{array}$} & \multicolumn{3}{|c|}{ Maximum State Death Tax Credit } \\
\hline Over & But less than & Base & $\begin{array}{l}\text { Marginal Credit } \\
\text { (in percents) }\end{array}$ & $\begin{array}{l}\text { Estate in } \\
\text { Excess of }\end{array}$ \\
\hline 0 & 40 & 0 & 0.0 & 0 \\
\hline 40 & 90 & 0 & 0.8 & 40 \\
\hline 90 & 140 & 400 & 1.6 & 90 \\
\hline 140 & 240 & 1,200 & 2.4 & 140 \\
\hline 240 & 440 & 3,600 & 3.2 & 240 \\
\hline 440 & 640 & 10,000 & 4.0 & 440 \\
\hline 640 & 840 & 18,000 & 4.8 & 640 \\
\hline 840 & 1,040 & 27,600 & 5.6 & 840 \\
\hline 1,040 & 1,540 & 38,800 & 6.4 & 1,040 \\
\hline 1,540 & 2,040 & 70,800 & 7.2 & 1,540 \\
\hline 2,040 & 2,540 & 106,800 & 8.0 & 2,040 \\
\hline 2,540 & 3,040 & 146,800 & 8.8 & 2,540 \\
\hline 3,040 & 3,540 & 190,800 & 9.6 & 3,040 \\
\hline 3,540 & 4,040 & 238,800 & 10.4 & 3,540 \\
\hline 4,040 & 5,040 & 290,800 & 11.2 & 4,040 \\
\hline 5,040 & 6,040 & 402,800 & 12.0 & 5,040 \\
\hline 6,040 & 7,040 & 522,800 & 12.8 & 6,040 \\
\hline 7,040 & 8,040 & 650,800 & 13.6 & 7,040 \\
\hline 8,040 & 9,040 & 786,800 & 14.4 & 8,040 \\
\hline 9,040 & 10,040 & 930,800 & 15.2 & 9,040 \\
\hline 10,040 & & $1,082,800$ & 16.0 & 10,040 \\
\hline
\end{tabular}

${ }^{\mathrm{a}}$ The adjusted taxable estate is equal to the taxable estate minus $\$ 60,000$.

Source: Internal Revenue Service Estate Tax Code 
Table 3. State-Based Effective Marginal Tax Rates after Federal Credits

\begin{tabular}{|c|c|c|c|c|c|c|c|}
\hline \multirow{2}{*}{\multicolumn{2}{|c|}{$\begin{array}{c}\text { Adjusted Taxable Estate }{ }^{\mathrm{a}} \\
(\$ 1,000 \mathrm{~s})\end{array}$}} & \multirow{3}{*}{$\begin{array}{c}\text { Federal Tax Rate after } \\
\text { Unified Credit } \\
\text { (3) }\end{array}$} & \multirow{3}{*}{$\begin{array}{l}\text { Federal Credit } \\
\text { for State Taxes } \\
\text { (4) }\end{array}$} & \multicolumn{3}{|c|}{ Average State Death Tax Rates } & \multirow{3}{*}{$\begin{array}{c}\text { State-Based Marginal Rate } \\
\text { Sponge versus Non-Sponge } \\
\text { Difference } \\
(8)\end{array}$} \\
\hline & & & & \multirow[b]{2}{*}{$\begin{array}{l}\text { All States } \\
(5)\end{array}$} & \multirow{2}{*}{$\begin{array}{l}\text { Sponge Tax } \\
\text { States } \\
(6)\end{array}$} & \multirow{2}{*}{$\begin{array}{c}\text { Non-Sponge } \\
\text { Tax States } \\
(7) \\
\end{array}$} & \\
\hline $\begin{array}{l}\text { Over } \\
(1)\end{array}$ & $\begin{array}{c}\text { But less than } \\
\text { (2) }\end{array}$ & & & & & & \\
\hline 0 & 600 & 0.0 & 4.0 & 4.7 & 4.0 & 6.5 & 2.5 \\
\hline 600 & 700 & 37.0 & 4.0 & 5.5 & 4.0 & 7.1 & 3.1 \\
\hline 700 & 750 & 37.0 & 4.8 & 5.5 & 4.8 & 7.1 & 2.3 \\
\hline 750 & 900 & 39.0 & 4.8 & 6.2 & 4.8 & 7.7 & 2.9 \\
\hline 900 & 1,000 & 39.0 & 5.6 & 6.2 & 5.6 & 7.6 & 2.0 \\
\hline 1,000 & 1,100 & 41.0 & 5.6 & 6.9 & 5.6 & 8.1 & 2.5 \\
\hline 1,100 & 1,250 & 41.0 & 6.4 & 6.9 & 6.4 & 8.2 & 1.8 \\
\hline 1,250 & 1,500 & 43.0 & 6.4 & 7.0 & 6.4 & 8.4 & 2.0 \\
\hline 1,500 & 1,600 & 45.0 & 6.4 & 7.7 & 6.4 & 8.8 & 2.4 \\
\hline 1,600 & 2,000 & 45.0 & 7.2 & 7.7 & 7.2 & 8.9 & 1.7 \\
\hline 2,000 & 2,100 & 49.0 & 7.2 & 8.4 & 7.2 & 9.3 & 2.1 \\
\hline 2,100 & 2,500 & 49.0 & 8.0 & 8.3 & 8.0 & 9.1 & 1.1 \\
\hline 2,500 & 2,600 & 53.0 & 8.0 & 9.0 & 8.0 & 9.6 & 1.6 \\
\hline 2,600 & 3,000 & 53.0 & 8.8 & 9.1 & 8.8 & 9.6 & 0.8 \\
\hline 3,000 & 3,100 & 55.0 & 8.8 & 9.8 & 8.8 & 10.2 & 1.4 \\
\hline 3,100 & 3,600 & 55.0 & 9.6 & 10.6 & 9.6 & 10.9 & 1.3 \\
\hline 3,600 & 4,100 & 55.0 & 10.4 & 11.3 & 10.4 & 11.7 & 1.3 \\
\hline 4,100 & 5,100 & 55.0 & 11.2 & 12.2 & 11.2 & 12.5 & 1.3 \\
\hline 5,100 & 6,100 & 55.0 & 12.0 & 12.9 & 12.0 & 13.3 & 1.3 \\
\hline 6,100 & 7,100 & 55.0 & 12.8 & 13.7 & 12.8 & 14.1 & 1.3 \\
\hline 7,100 & 8,100 & 55.0 & 13.6 & 14.5 & 13.6 & 14.8 & 1.2 \\
\hline 8,100 & 9,100 & 55.0 & 14.4 & 15.3 & 14.4 & 15.6 & 1.2 \\
\hline 9,100 & 10,000 & 55.0 & 15.2 & 16.1 & 15.2 & 16.3 & 1.1 \\
\hline 10,000 & 10,100 & 60.0 & 15.2 & 16.1 & 15.2 & 16.3 & 1.1 \\
\hline 10,100 & 21,040 & 60.0 & 16.0 & 16.1 & 16.0 & 16.3 & 0.3 \\
\hline 21,040 & and over & 55.0 & 16.0 & 16.1 & 16.0 & 16.3 & 0.3 \\
\hline
\end{tabular}

${ }^{\mathrm{a}}$ The adjusted taxable estate is equal to the taxable estate minus $\$ 60,000$.

Source: Authors' tabulations of the Estate Tax Codes of 50 States and the District of Columbia and the Internal Revenue Service. 
Table 4. Descriptive Statistics

\begin{tabular}{|c|c|c|c|}
\hline Variable & Mean & Median & Standard Deviation \\
\hline Net Worth & 251,647 & 67,358 & $704,690.9$ \\
\hline $\ln$ Net Worth & 10,872 & 11,118 & 2.225 \\
\hline \multicolumn{4}{|l|}{ Desired Bequest } \\
\hline Very Important & 0.241 & 0 & 0.428 \\
\hline Important & 0.646 & 1 & 0.478 \\
\hline \multicolumn{4}{|l|}{ Estate Tax } \\
\hline $\ln \left(1+\mu_{B}\right)$ & 0.0351 & 0.0266 & 0.0364 \\
\hline$\tau$ & 3.387 & 2.647 & 3.407 \\
\hline \multicolumn{4}{|l|}{ Income Tax } \\
\hline $\ln \left(1+\mu_{1}\right)$ & -0.00872 & 0 & 0.0735 \\
\hline$\theta$ & 16.42 & 20.7 & 17.161 \\
\hline Age & 55.92 & 56 & 3.21 \\
\hline Age Squared & $3,091.56$ & 3,136 & 388.19 \\
\hline Have Children & 0.778 & 1 & 0.415 \\
\hline Female & 0.68 & 1 & 0.544 \\
\hline Black & 0.184 & 0 & 0.387 \\
\hline Non-Black, Non White & 0.0408 & 0 & 0.198 \\
\hline \multicolumn{4}{|l|}{ Education } \\
\hline High School & 0.337 & 0 & 0.473 \\
\hline College & 0.208 & 0 & 0.406 \\
\hline \multicolumn{4}{|l|}{ Health } \\
\hline Excellent & 0.2 & 0 & 0.4 \\
\hline Very Good & 0.252 & 0 & 0.434 \\
\hline Fair & 0.171 & 0 & 0.376 \\
\hline Poor & 0.117 & 0 & 0.322 \\
\hline \multicolumn{4}{|l|}{ Change in Health } \\
\hline Much Better & 0.0573 & 0 & 0.232 \\
\hline Better & 0.0936 & 0 & 0.291 \\
\hline Worse & 0.125 & 0 & 0.33 \\
\hline Much Worse & 0.0414 & 0 & 0.199 \\
\hline \multicolumn{4}{|l|}{ Probability } \\
\hline Live to 75 (out of 10 ) & 6.27 & 7 & 3.11 \\
\hline Live to 85 (out of 10 ) & 4.25 & 4 & 3.31 \\
\hline Received Inheritance & 0.175 & 0 & 0.38 \\
\hline Divorced & 0.795 & 1 & 0.404 \\
\hline $\mathrm{N}$ & 2,463 & 2,463 & 2,463 \\
\hline
\end{tabular}


Table 5. Capital Taxes and Wealth Accumulation

\begin{tabular}{|c|c|c|}
\hline & \multicolumn{2}{|c|}{ Dependent Variable: Logarithm of Net Worth } \\
\hline & OLS & IV \\
\hline Constant & $\begin{array}{c}12.2 \\
(0.902)\end{array}$ & $\begin{array}{c}6.97 \\
(2.92)\end{array}$ \\
\hline $\ln \left(1+\mu_{B}\right)$ Estate Tax & $\begin{array}{l}24.4 \\
(2.09)\end{array}$ & $\begin{array}{l}-37.8 \\
(18.5)\end{array}$ \\
\hline $\ln \left(1+\mu_{1}\right)$ Income Tax & $\begin{array}{c}3.05 \\
(0.577)\end{array}$ & $\begin{array}{l}-3.75 \\
(9.78)\end{array}$ \\
\hline Age & $\begin{array}{l}-0.0329 \\
(0.0269)\end{array}$ & $\begin{array}{c}0.0202 \\
(0.0473)\end{array}$ \\
\hline Age Squared & $\begin{array}{l}0.0000163 \\
(0.000240)\end{array}$ & $\begin{array}{c}0.00117 \\
(0.000456)\end{array}$ \\
\hline Have Children & $\begin{array}{l}0.0681 \\
(0.121)\end{array}$ & $\begin{array}{l}-0.396 \\
(0.443)\end{array}$ \\
\hline Female & $\begin{array}{c}-0.263 \\
(0.0828)\end{array}$ & $\begin{array}{c}1.11 \\
(0.582)\end{array}$ \\
\hline Black & $\begin{array}{c}-0.586 \\
(0.0852)\end{array}$ & $\begin{array}{l}-0.901 \\
(0.236)\end{array}$ \\
\hline Non-Black, Non-White & $\begin{array}{l}-0.433 \\
(0.220)\end{array}$ & $\begin{array}{l}-0.652 \\
(0.348)\end{array}$ \\
\hline $\begin{array}{l}\text { Education: } \\
\text { High School }\end{array}$ & $\begin{array}{c}0.0860 \\
(0.0862)\end{array}$ & $\begin{array}{c}0.318 \\
(0.155)\end{array}$ \\
\hline College & $\begin{array}{c}0.670 \\
(0.111)\end{array}$ & $\begin{array}{c}1.80 \\
(0.521)\end{array}$ \\
\hline $\begin{array}{l}\text { Health: } \\
\text { Excellent }\end{array}$ & $\begin{array}{c}0.145 \\
(0.119)\end{array}$ & $\begin{array}{c}0.614 \\
(0.257)\end{array}$ \\
\hline Very Good & $\begin{array}{c}0.217 \\
(0.0998)\end{array}$ & $\begin{array}{c}0.719 \\
(0.259)\end{array}$ \\
\hline Fair & $\begin{array}{l}-0.385 \\
(0.128)\end{array}$ & $\begin{array}{l}-0.616 \\
(0.205)\end{array}$ \\
\hline Poor & $\begin{array}{l}-0.517 \\
(0.167)\end{array}$ & $\begin{array}{l}-1.15 \\
(0.295)\end{array}$ \\
\hline
\end{tabular}


Table 5. Continued

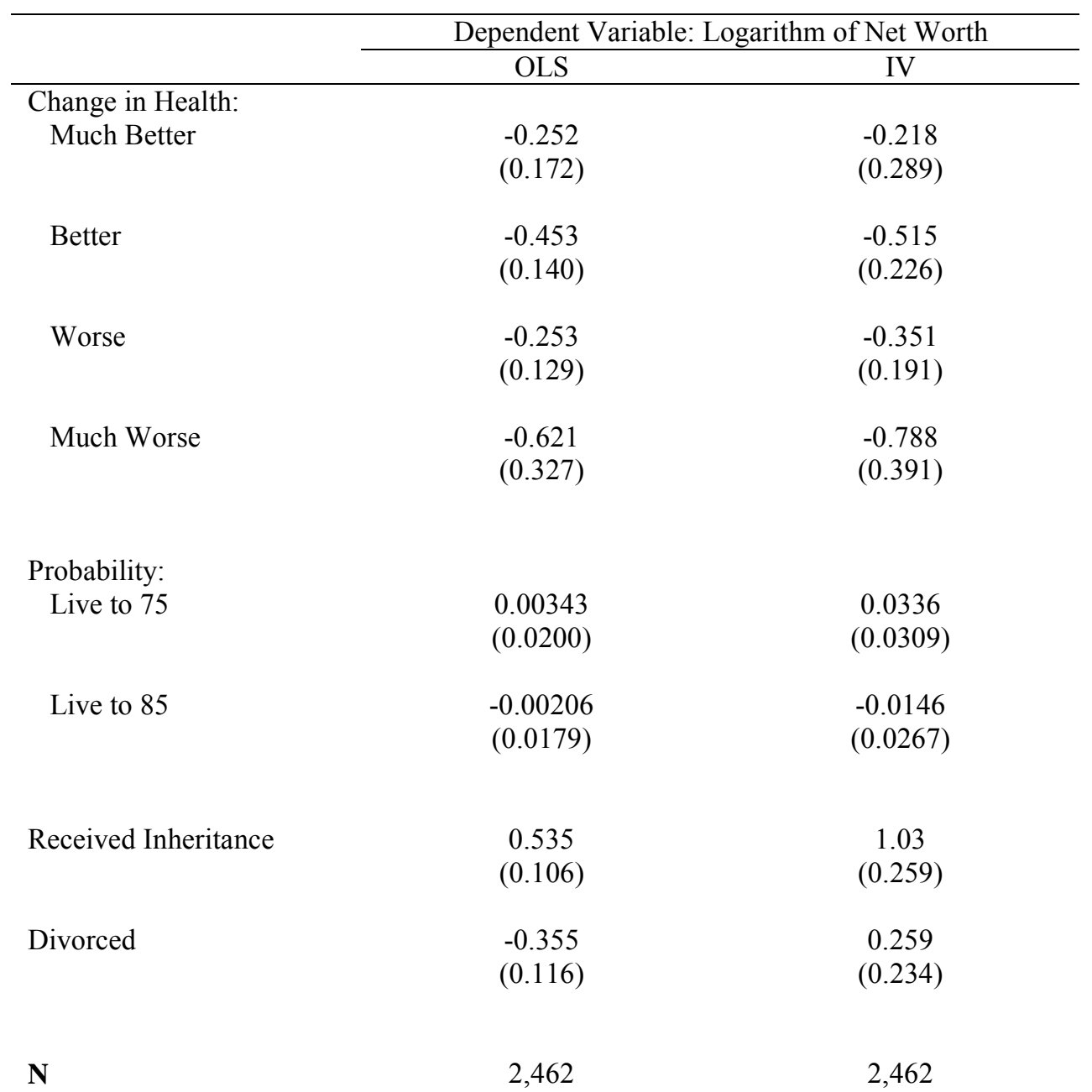


Table 6. Capital Taxes and Wealth Accumulation:

Robustness Checks

\begin{tabular}{lcc}
\hline & $\begin{array}{c}\text { Estate Tax } \\
\ln \left(1+\mu_{B}\right)\end{array}$ & $\begin{array}{c}\text { Income Tax } \\
\ln \left(1+\mu_{1}\right)\end{array}$ \\
\hline IV, Direct Controls for Demographic Groups & -39.1 & -3.56 \\
& $(21.2)$ & $(9.95)$ \\
IV, State Dummy Variables & -14.8 & 17.4 \\
& $(12.4)$ & $(8.16)$ \\
IV, Direct Controls for Demographic Groups + State & -16.6 & 17.7 \\
Dummy Variables & $(14.2)$ & $(8.84)$ \\
IV, Interact with Have Children & & 1.19 \\
Direct & -18.4 & $(6.70)$ \\
& $(6.70)$ & -- \\
Interactive & -2.73 & \\
IV, Tax Price Specification & $(10.4)$ & -2.83 \\
& 25.5 & $(5.49)$ \\
IV, Marginal Tax Rate Specification & $(18.3)$ & 0.141 \\
& -33.0 & $(5.59)$ \\
\end{tabular}


Table 7. Capital Taxes and Desired Bequests

\begin{tabular}{|c|c|c|c|}
\hline & \multicolumn{2}{|c|}{ Linear Probability Model } & \multirow{2}{*}{$\begin{array}{c}\text { Probit Model } \\
\text { IV }\end{array}$} \\
\hline & OLS & IV & \\
\hline Constant & $\begin{array}{c}0.429 \\
(0.165)\end{array}$ & $\begin{array}{l}-0.648 \\
(0.630)\end{array}$ & $\begin{array}{l}-3.10 \\
(1.58)\end{array}$ \\
\hline $\ln \left(1+\mu_{B}\right)$ Estate Tax & $\begin{array}{c}0.455 \\
(0.301)\end{array}$ & $\begin{array}{l}-8.48 \\
(4.33)\end{array}$ & $\begin{array}{l}-23.3 \\
(10.7)\end{array}$ \\
\hline Residual & & & $\begin{array}{c}24.8 \\
(10.8)\end{array}$ \\
\hline $\ln \left(1+\mu_{1}\right)$ Income Tax & $\begin{array}{l}-0.0157 \\
(0.137)\end{array}$ & $\begin{array}{l}-2.76 \\
(2.09)\end{array}$ & $\begin{array}{l}-7.70 \\
(5.27)\end{array}$ \\
\hline Residual & & & $\begin{array}{c}7.62 \\
(5.29)\end{array}$ \\
\hline Age & $\begin{array}{c}0.00267 \\
(0.00455)\end{array}$ & $\begin{array}{c}0.0152 \\
(0.0100)\end{array}$ & $\begin{array}{c}0.0411 \\
(0.0250)\end{array}$ \\
\hline Age Squared & $\begin{array}{l}-0.0000315 \\
(0.0000425)\end{array}$ & $\begin{array}{l}0.000136 \\
(0.0000977)\end{array}$ & $\begin{array}{c}0.000384 \\
(0.000258)\end{array}$ \\
\hline Have Children & $\begin{array}{c}0.145 \\
(0.0313)\end{array}$ & $\begin{array}{c}0.0135 \\
(0.0954)\end{array}$ & $\begin{array}{r}0.0186 \\
(0.229)\end{array}$ \\
\hline Female & $\begin{array}{r}0.00297 \\
(0.0222)\end{array}$ & $\begin{array}{c}0.243 \\
(0.126)\end{array}$ & $\begin{array}{c}0.670 \\
(0.317)\end{array}$ \\
\hline Black & $\begin{array}{c}0.106 \\
(0.0219)\end{array}$ & $\begin{array}{c}0.0349 \\
(0.0508)\end{array}$ & $\begin{array}{c}0.111 \\
(0.131)\end{array}$ \\
\hline Non-Black, Non-White & $\begin{array}{c}0.0728 \\
(0.0473)\end{array}$ & $\begin{array}{c}0.0144 \\
(0.0660)\end{array}$ & $\begin{array}{c}0.359 \\
(0.185)\end{array}$ \\
\hline $\begin{array}{l}\text { Education: } \\
\text { High School }\end{array}$ & $\begin{array}{l}-0.0145 \\
(0.0217)\end{array}$ & $\begin{array}{c}0.0224 \\
(0.0329)\end{array}$ & $\begin{array}{c}0.596 \\
(0.845)\end{array}$ \\
\hline College & $\begin{array}{c}0.0200 \\
(0.0273)\end{array}$ & $\begin{array}{c}0.225 \\
(0.113)\end{array}$ & $\begin{array}{c}0.626 \\
(0.285)\end{array}$ \\
\hline $\begin{array}{l}\text { Health: } \\
\text { Excellent }\end{array}$ & $\begin{array}{l}-0.0486 \\
(0.0301)\end{array}$ & $\begin{array}{c}0.0331 \\
(0.0580)\end{array}$ & $\begin{array}{c}0.0860 \\
(0.138)\end{array}$ \\
\hline Very Good & $\begin{array}{l}-0.00403 \\
(0.0265)\end{array}$ & $\begin{array}{c}0.0838 \\
(0.0579)\end{array}$ & $\begin{array}{c}0.226 \\
(0.144)\end{array}$ \\
\hline Fair & $\begin{array}{c}0.0112 \\
(0.0292)\end{array}$ & $\begin{array}{l}-0.0519 \\
(0.0425)\end{array}$ & $\begin{array}{l}-0.147 \\
(0.110)\end{array}$ \\
\hline Poor & $\begin{array}{l}-0.0127 \\
(0.0370)\end{array}$ & $\begin{array}{l}-0.0940 \\
(0.0595)\end{array}$ & $\begin{array}{l}-0.266 \\
(0.158)\end{array}$ \\
\hline
\end{tabular}


Table 7. Continued

\begin{tabular}{|c|c|c|c|}
\hline & \multicolumn{2}{|c|}{ Linear Probability Model } & \multirow{2}{*}{$\begin{array}{c}\text { Probit Model } \\
\text { IV }\end{array}$} \\
\hline & OLS & IV & \\
\hline Change in Health: & & & \\
\hline Much Better & $\begin{array}{c}0.0269 \\
(0.0379)\end{array}$ & $\begin{array}{c}0.0612 \\
(0.0601)\end{array}$ & $\begin{array}{c}0.175 \\
(0.154)\end{array}$ \\
\hline Better & 0.00768 & 0.0183 & 0.047 \\
\hline Worse & $\begin{array}{l}-0.0347 \\
(0.0311)\end{array}$ & $\begin{array}{l}-0.0389 \\
(0.0395)\end{array}$ & $\begin{array}{l}-0.110 \\
(0.107)\end{array}$ \\
\hline Much Worse & $\begin{array}{l}-0.0533 \\
(0.0528)\end{array}$ & $\begin{array}{l}-0.0770 \\
(0.0639)\end{array}$ & $\begin{array}{l}-0.211 \\
(0.164)\end{array}$ \\
\hline Probability: & & & \\
\hline Live to 75 & $\begin{array}{c}0.00313 \\
(0.00464)\end{array}$ & $\begin{array}{c}0.00927 \\
(0.00648)\end{array}$ & $\begin{array}{c}0.0266 \\
(0.0184)\end{array}$ \\
\hline Live to 85 & $\begin{array}{l}-0.00365 \\
(0.00427)\end{array}$ & $\begin{array}{l}-0.00657 \\
(0.00540)\end{array}$ & $\begin{array}{l}-0.0186 \\
(0.0148)\end{array}$ \\
\hline Received Inheritance & $\begin{array}{c}0.0560 \\
(0.0268)\end{array}$ & $\begin{array}{c}0.144 \\
(0.0567)\end{array}$ & $\begin{array}{c}0.403 \\
(0.151)\end{array}$ \\
\hline Divorced & $\begin{array}{c}0.0320 \\
(0.0290)\end{array}$ & $\begin{array}{c}0.112 \\
(0.0547)\end{array}$ & $\begin{array}{l}-3.16 \\
(0.155)\end{array}$ \\
\hline $\mathrm{N}$ & 2,462 & 2,462 & 2,462 \\
\hline
\end{tabular}


Table 8. Capital Taxes and Desired Bequests:

Robustness Checks

\begin{tabular}{lcc}
\hline & $\begin{array}{c}\text { Estate Tax } \\
\ln \left(1+\mu_{B}\right)\end{array}$ & $\begin{array}{c}\text { Income Tax } \\
\ln \left(1+\mu_{1}\right)\end{array}$ \\
\hline IV, Direct Controls for Demographic Groups & -24.8 & -7.58 \\
& $(10.9)$ & $(5.03)$ \\
IV, State Dummy Variables & -11.5 & -0.767 \\
& $(10.6)$ & $(2.23)$ \\
IV, Direct Controls for Demographic Groups + State & -12.5 & -0.887 \\
Dummy Variables & $(3.41)$ & $(2.39)$ \\
IV, Interact with Have Children & & -6.64 \\
Direct & -21.0 & $(4.81)$ \\
& $(8.46)$ & -- \\
Interactive & -0.178 & \\
IV, Tax Price Specification & $(0.161)$ & 6.44 \\
IV, Marginal Tax Rate Specification & 28.9 & $(3.00)$ \\
\end{tabular}


Figure 1

Efficiency Gains and Wealth Distribution

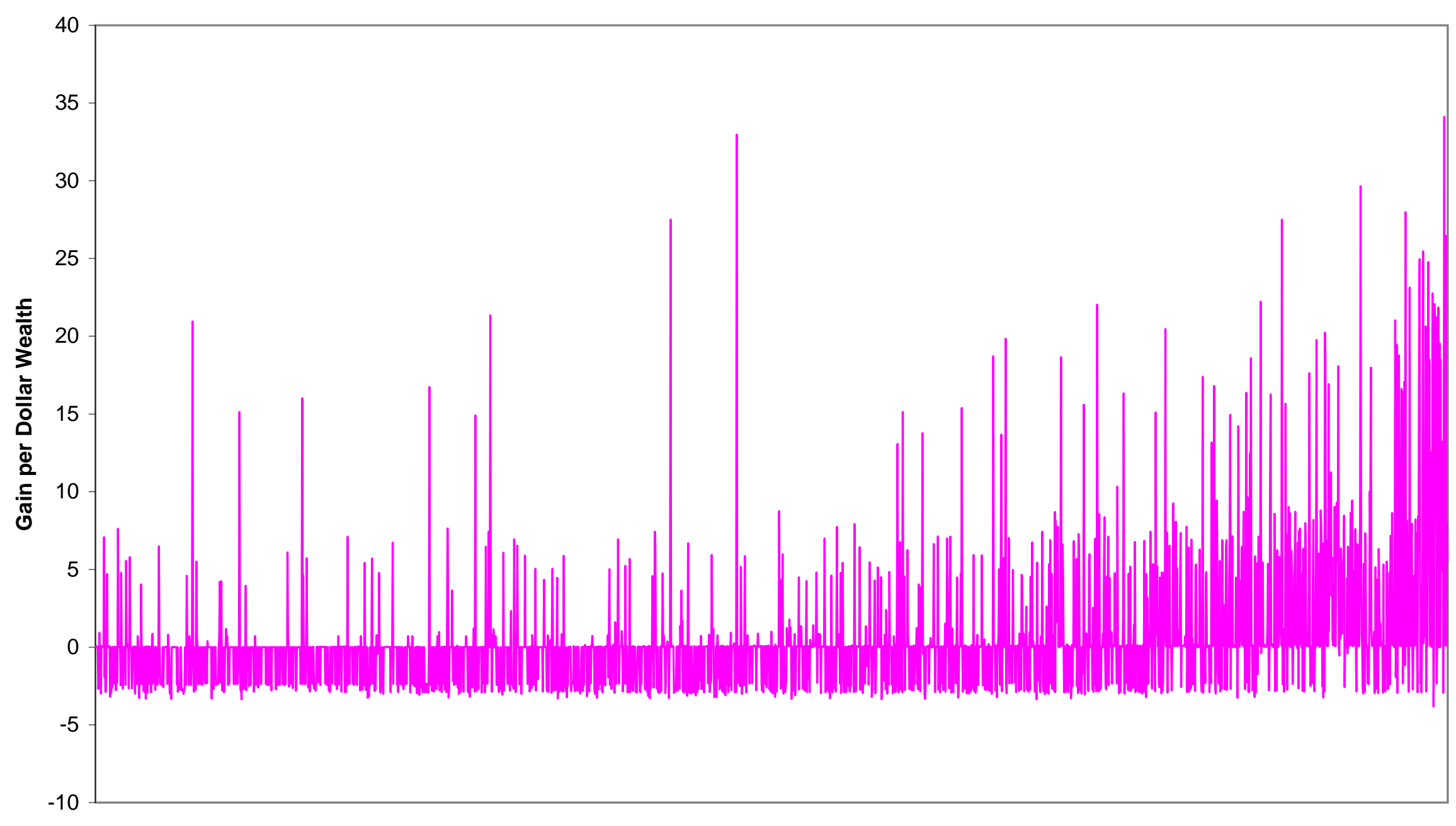

Percentile of Distribution 
Figure 2

Effect of Bequest Elasticity

Distribution of Efficiency Gains

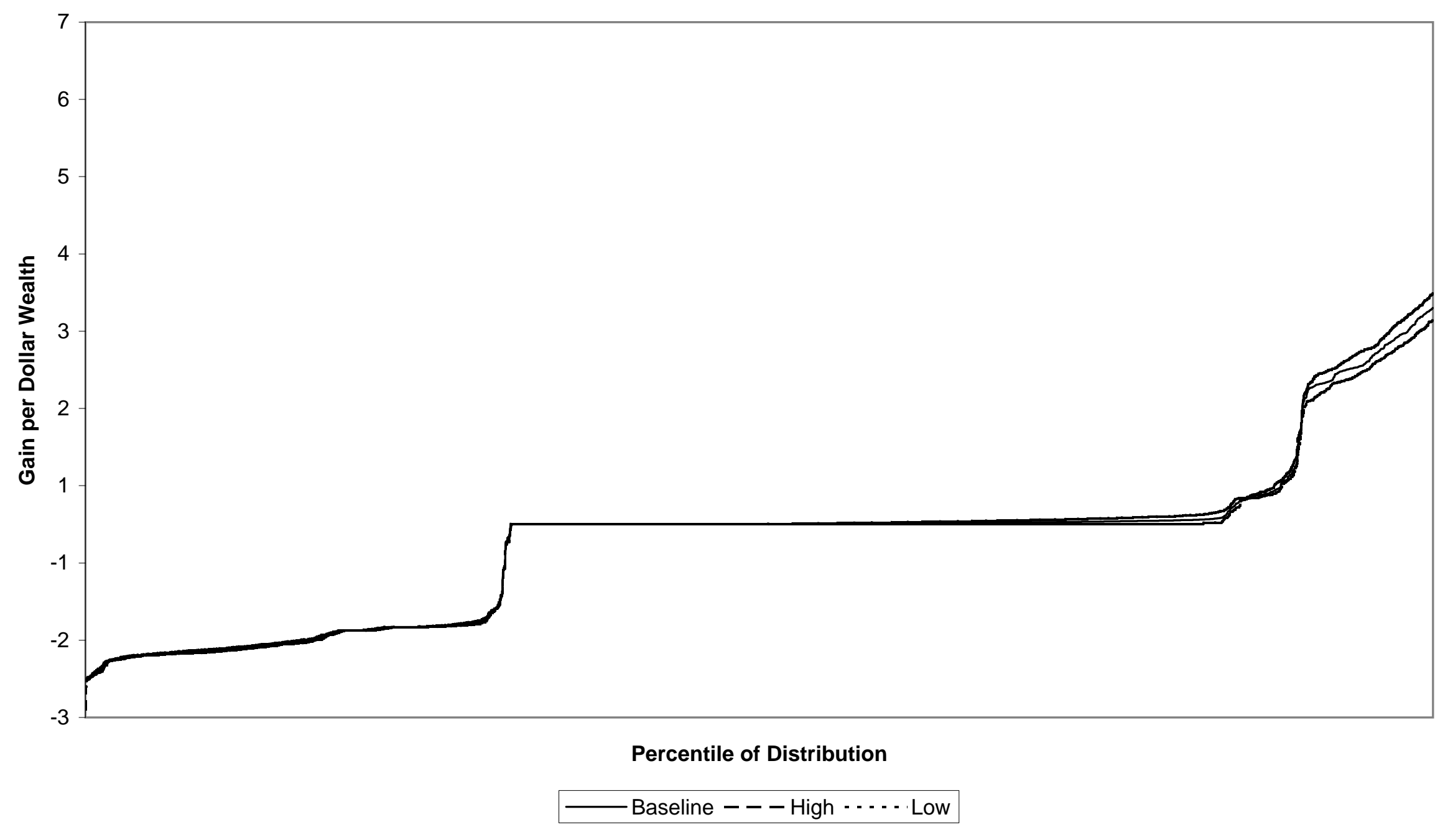


Figure 3

Effect of Wealth-Estate Tax Elasticity

Distribution of Efficiency Gains

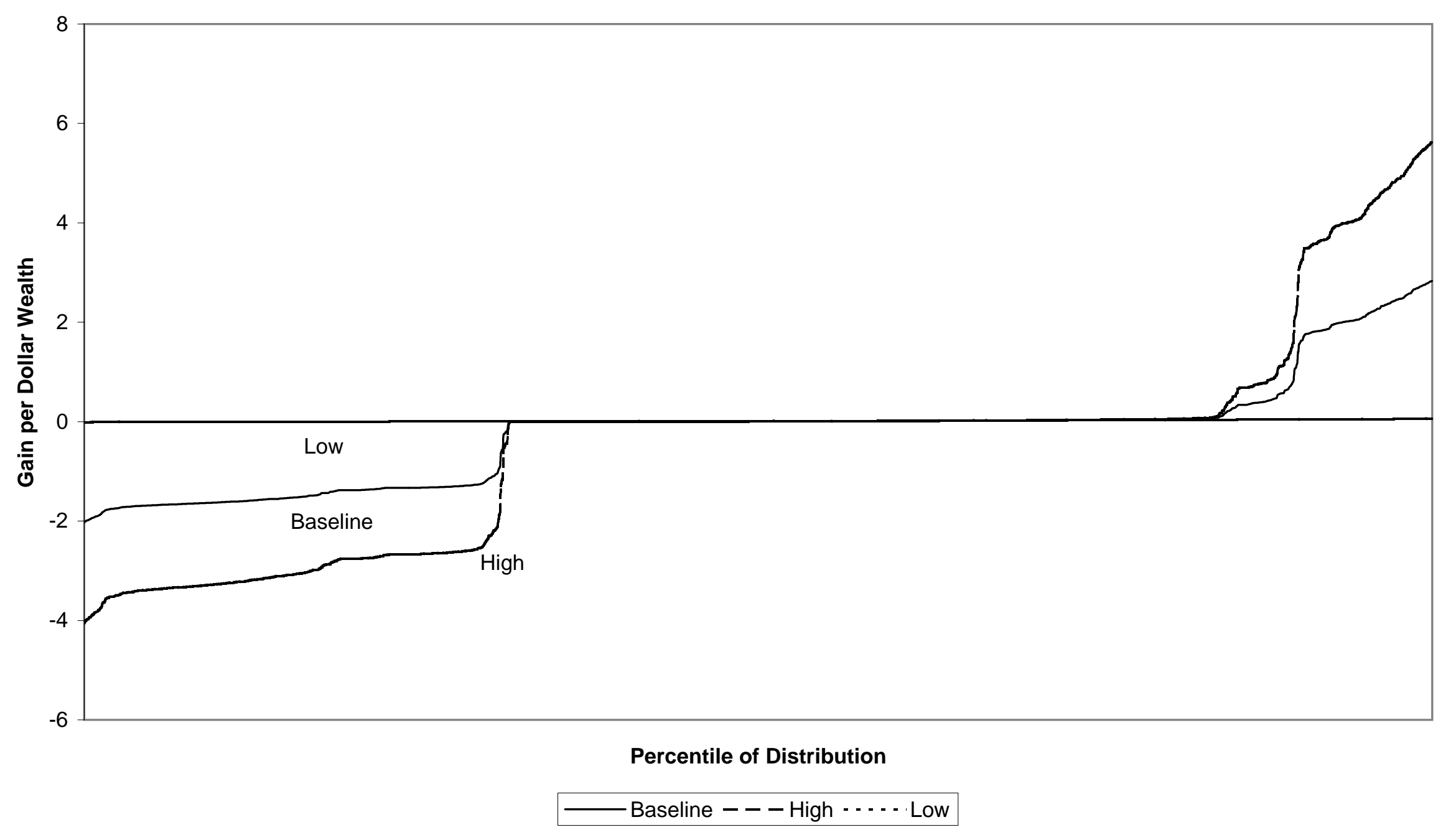


Figure 4

Effect of Wealth-Income Tax Elasticity

Distribution of Efficiency Gains

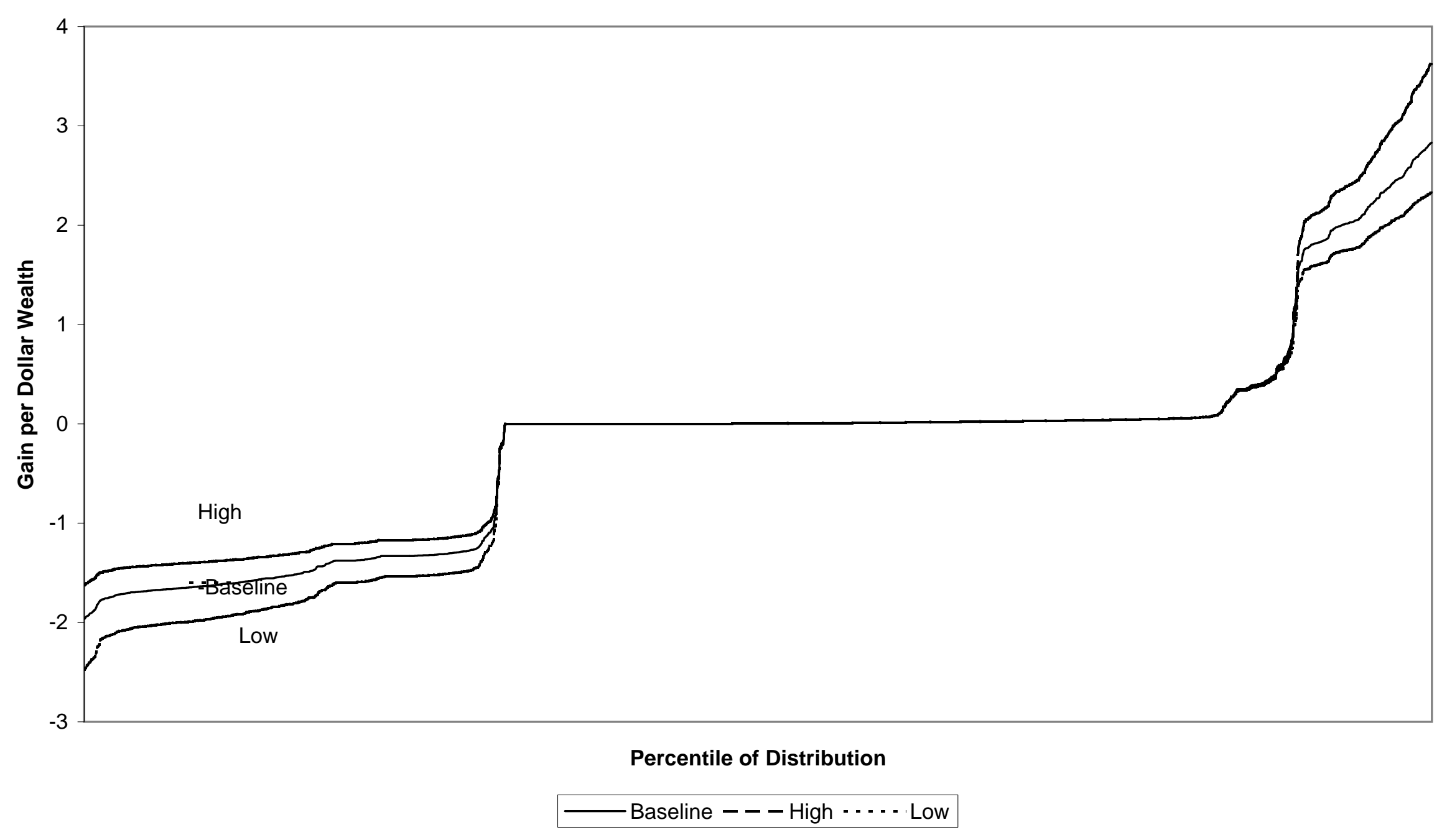

